NBER WORKING PAPER SERIES

\title{
WHAT HINDERS INVESTMENT IN THE AFTERMATH OF FINANCIAL CRISES: INSOLVENT FIRMS OR ILLIQUID BANKS?
}

\author{
Sebnem Kalemli-Ozcan \\ Herman Kamil \\ Carolina Villegas-Sanchez \\ Working Paper 16528 \\ http://www.nber.org/papers/w16528
}

\author{
NATIONAL BUREAU OF ECONOMIC RESEARCH \\ 1050 Massachusetts Avenue \\ Cambridge, MA 02138 \\ November 2010
}

We thank Asim Khawaja and three anonymous referees for their constructive comments. We also thank Laura Alfaro, Hoyt Bleakley, Roberto Chang, Fritz Foley, Mario Crucini, Aimee Chin, Philipp Schnabl and Bent Sorensen for valuable suggestions and the participants of the seminar at Alicante, Bank of Spain, Brown University, Dartmouth, ESADE, McGill University, Rice University, University of Texas at Austin, Stockholm School of Economics, Valencia University, 10th Jacques Polak IMF Annual Research Conference, 2010 NBER-IFM Spring Meeting, and 2010 LACEA Meetings for their comments. Carolina Villegas-Sanchez acknowledges financial support from Banco Sabadell. The views expressed herein are those of the authors and do not necessarily reflect the views of the National Bureau of Economic Research.

NBER working papers are circulated for discussion and comment purposes. They have not been peerreviewed or been subject to the review by the NBER Board of Directors that accompanies official NBER publications.

(C) 2010 by Sebnem Kalemli-Ozcan, Herman Kamil, and Carolina Villegas-Sanchez. All rights reserved. Short sections of text, not to exceed two paragraphs, may be quoted without explicit permission provided that full credit, including $(\mathcal{C}$ notice, is given to the source. 
What Hinders Investment in the Aftermath of Financial Crises: Insolvent Firms or Illiquid Banks?

Sebnem Kalemli-Ozcan, Herman Kamil, and Carolina Villegas-Sanchez

NBER Working Paper No. 16528

November 2010, Revised July 2015

JEL No. E32,F15,F23,F36,O16

\begin{abstract}
We quantify the effects of lending and balance sheet channels on corporate investment during large crises in emerging markets. The depreciated currency creates investment opportunities in the tradable sector but firms might be financially constrained due to: 1) a deterioration of their balance sheet via un-hedged foreign currency debt (balance sheet channel) and 2) a decline in the supply of credit by banks (lending channel). We find that during twin crises, domestic exporters holding un-hedged foreign currency debt decrease investment while foreign exporters with better access to credit increase investment, in spite of their un-hedged foreign currency debt. We do not find such a differential effect under pure currency crises. Using firm-bank matched data during global financial crisis, we show that both domestic and foreign-owned firms experienced a decline in bank credit from affected banks however, foreignowned firms substituted the lost credit.
\end{abstract}

\author{
Sebnem Kalemli-Ozcan \\ Department of Economics \\ University of Maryland \\ Tydings Hall 4118D \\ College Park, MD 20742-7211 \\ and CEPR \\ and also NBER \\ kalemli@econ.umd.edu \\ Herman Kamil \\ International Monetary Fund \\ Western Hemisphere Department \\ 700 19th Street, NW \\ Washington DC, 20431 \\ hkamil@imf.org \\ Carolina Villegas-Sanchez \\ ESADE Business School \\ Barcelona \\ Spain \\ carolina.villegas@esade.edu
}




\section{Introduction}

A central debate in finance and macroeconomics is whether financial frictions operate mostly via the bank lending channel or the firm balance sheet channel in turning financial crises into recessions. Quantifying the effects of both channels on corporate investment simultaneously has been proven difficult. This is the task we undertake in this paper. A key advantage of our approach is that we employ a unique data set that allows to account for the ability of firms to borrow based on their net worth (balance sheet channel) and the ability of banks to lend (the supply of credit/lending channel), separately. Based on such strategy we measure the relative importance of the lending and balance sheet channels on corporate investment simultaneously.

We utilize the experience of Latin American countries with a range of financial crises during 1990-2005. These often involved a currency crisis but also a twin crisis episode, where prior to the currency crash the banking system collapsed, as shown by Kaminsky and Reinhart (1999) and Reinhart and Rogoff $(2010)$. Both types of financial crises - currency and twin-feature the depreciation of the currency and therefore, a willingness of exporting firms to invest and exploit competitiveness effects via a depreciated currency. Hence, a currency crisis constitutes a positive shock to credit demand. The two types of crises differ in the supply of credit by local banks, namely the lending channel is more relevant during twin crises where supply of credit contracts relatively more than in the case of currency crises.

Given the extensive foreign currency borrowing in emerging markets in the 1990s, both currency and twin crises are characterized by changes in firm's debt burden and net worth. We expect firms with high dollar debt and no hedge (such as export revenue, derivatives or dollar assets) to decrease investment regardless of the type of crisis due to the negative shock to their collateral resulting from the balance sheet weakness caused by the depreciated currency (balance sheet channel). Only exporting firms with enough dollar denominated streams of income can compensate changes in the value of foreign currency denominated debt and hence, may not be affected from the balance sheet channel. Such solvent firms should increase investment unless the illiquid local banking sector poses 
a problem. There will be a liquidity supply problem (lending channel) during a twin crisis.

We study four episodes of currency crises (Mexico 1995, Argentina 2002, Brazil 1999 and 2002) using a triple difference-in-difference methodology. Two of these episodes were twin crises since they were combined with a banking crisis (Mexico 1994 and Argentina 2001). In order to have firm level measures of insolvency and liquidity over time, we have hand-collected a unique panel database with annual accounting information for the whole universe of listed non-financial companies in these Latin American countries, spanning the period 1990 to 2005. We define an insolvent firm as one with high leverage and holdings of short-term foreign currency denominated debt that are not matched by a dollar denominated stream of income ${ }^{1}$ These firms are naturally more likely to experience a decline in net worth in the aftermath of large exchange rate devaluations. Aguiar (2005) shows that firms with heavy exposure to short-term foreign currency debt before the Mexican crisis decreased investment compared to firms with lower dollar debt exposure. Bleakley and Cowan (2008) show the opposite result, where firms holding dollar debt invest more during exchange rate depreciations. They are the first to argue that firms match the currency composition of their liabilities with that of their income streams or assets, avoiding insolvency during a currency depreciation. Hence we make sure our insolvent firms are the ones with un-hedged foreign currency debt.

We measure the liquidity shock, first, at the country level, by focusing on twin crisis episodes that are characterized by a general dry up of credit in the year prior to the currency crisis for all firms. Second, we use foreign ownership (FDI and portfolio equity investment) as our preferred firm level measure of access to liquidity. Desai, Foley, and Hines (2004) show how multinational affiliates use internal capital markets in financially underdeveloped markets. Desai, Foley, and Forbes (2008) investigate the response of sales, assets, and capital expenditure of U.S. multinational affiliates and domestic firms in the aftermath of a variety of financial crises from 25 emerging market countries and find that foreign affiliates outperform their local counterparts across these performance measures. Their interpretation is that local firms are financially constrained due to their limited access to

\footnotetext{
${ }^{1}$ This is based on Allen, Rosenberg, Keller, Setser, and Roubini (2002).
} 
finance. Hence, building on their work we will use foreign ownership as our access to finance measure. We will test this assumption using firm-bank matched data from Mexico and show that when exposed to the same bank-level liquidity shock, foreign-owned firms, as opposed to domestic firms, are able to substitute bank credit.

Our main specification regresses firm level investment on a triple interaction of foreign ownership with balance sheet weakness in a sample of exporters during currency crises and twin crises. We show that, conditional on their balance sheet weakness, foreign-owned exporters invest relatively more than domestic exporters only during twin crises. There is no difference in investment rates among these groups during currency crises. During twin crises, domestic exporters suffer a negative liquidity shock being unable to roll over short-term debt and exploit growth opportunities. Their investment is 10 percentage points lower than that of foreign-owned exporters where both groups hold similar levels of dollar debt, mostly un-hedged. This is a sizeable difference between the groups since the average firm in our twin crises countries decreased investment by 20 percentage points during such crises. The average domestic exporter decreased investment by 13 percentage points, whereas the average foreign-owned exporter increased investment by 7 percentage points. Our results point to the key role of illiquidity rather than insolvency as the main source of financial constraint that hinders investment. This does not mean insolvency due to balance sheet weakness is not important but rather availability of credit in the face of good investment opportunities can overcome short-term balance sheet vulnerability.

Our key contribution over past studies that show the better performance of foreign-owned firms during a variety of crises is that we document the exact mechanism by which financial crises intensify financing constraints. We narrow down the possible set of financial constraints and quantify their effects during financial crises. It is possible that foreign-owned exporters have more resilient balance sheets based on matching dollar income. Or simply, foreigners might be better at managing their balance sheet exposures. In any of these cases, foreign-owned exporters will enjoy higher net worth and be considered solvent firms in the aftermath of large devaluations. This creates a selection 
problem, and makes it impossible to differentiate whether the better performance of foreign-owned exporters during financial crises is due to better access to liquidity or higher net worth. The strength of our data set is precisely observing the foreign currency denomination of the debt together with the foreign ownership status of the firm to account for this bias.

Our key identifying assumption is that conditional on holding un-hedged dollar debt prior to the crisis, access to credit is the only difference between foreign-owned and domestic exporters that explains differences in investment rates. Since it is possible that foreign-owned exporters differ from domestic exporters in many other dimensions than access to credit, we control for all such differences by including foreign-year fixed effects in all specifications. These fixed effects will absorb time varying differences before and after the shock in investment rates and determinants of these rates between foreign-owned and domestic exporters.

Notice the difference in investment rates between these two groups of firms is only present during twin crises when the supply of credit by local banks was interrupted, and not during currency crises. We therefore, attribute the divergence in investment rates to differences in access to liquidity at the time of the crisis. This interpretation assumes that any remaining difference between foreign-owned exporters with un-hedged dollar debt and domestic exporters with un-hedged dollar debt is not correlated with differences in investment rates and access to finance simultaneously. For example, the possibility of foreign-owned exporters switching destination markets, cannot fully account for our findings. It must be the case that only foreign-owned exporters with high levels of un-hedged dollar debt, and only during twin crises, switch destination markets (so differential demand shocks for foreign-owned exporters with high un-hedged dollar debt during a twin crisis). We undertake a series of robustness tests that help to corroborate our interpretation.

To further stress the importance of accounting for foreign-year fixed effects, assume that foreignowned exporters show higher asset tangibility, and thus have easier access to credit at all times not only during crisis periods. This is a permanent difference between foreign-owned and domestic exporters and will be absorbed by the foreign-year fixed effects since these fixed effects include 
foreign dummies by construction. Similarly, it is also possible that the nature of sectors in which foreigners operate changes over time and for example, some sectors need less external financing than others; sector-year fixed effects will take care of such trends. The use of sector-year fixed effects accounts for all industry supply and demand shocks that are common to all firms within an industry. If access to credit in some sectors is less stringent exactly at the moment of the crisis and foreigners happen to be in those sectors in advance, utilizing foreign-year dummies will fully control such selection at the moment of crisis both at the firm and at the sector level ${ }^{2}$ Finally, the multi-country panel dimension of our data allows us to condition on many country specific policy changes and other macroeconomic shocks through the use of country-year fixed effects, such as valuation effects and country-specific trends.

Why is the "access to finance" difference between foreign-owned and domestic exporters not absorbed by foreign-year fixed effects? Most likely there is a difference in terms of access to finance between these groups even during normal times and it is indeed absorbed by the foreign-year fixed effects. What is not absorbed by these fixed effects is the access to finance difference between the foreign-owned and domestic exporters who hold high levels of un-hedged dollar debt at the time of the crisis. Hence, our findings also indicate that there is an interaction between access to finance and balance sheet strength, where high levels of un-hedged dollar debt prevents domestic exporters to access external finance. This shows the importance of conditioning on balance sheet weakness when investigating the effect of foreign ownership on performance during crises.

A final caveat is the fact that we treat balance sheet and lending channel shocks asymmetrically, i.e., we have a firm level measure of the balance sheet shock but we do not have a firm level measure of the lending shock. In fact, the literature has shown that the most straightforward way to identify the lending channel is to investigate the behavior of firms borrowing from multiple banks as in Khwaja and Mian (2008) for Pakistan, Jimenez, Ongena, Peydro-Alcalde, and Saurina (2012) for Spain, Amiti and Weinstein (2013) for Japan, and Paravisini, Rappoport, Schnabl, and Wolfenzon

\footnotetext{
${ }^{2}$ Notice we define foreign ownership based on predetermined values three years prior to the crisis and therefore, foreign dummies do not vary over time.
} 
(2015) for Peru. The last part of our paper uses firm-bank matched data from Mexico and follows this literature to identify the lending channel. This will help us to test our assumption of foreign ownership being a measure for access to finance. Since we have the foreign-owned firm and domestic firm borrowing from the same bank, they will be exposed to the same credit supply shock. We then trace if domestic and foreign-owned firms can substitute the lost credit differentially. We show that foreign-owned firms can substitute but domestic firms cannot, where both borrowed from the same bank which got hit by the shock. This finding justifies our assumption of foreign ownership being an "access to finance" measure during twin crises times when the credit is tight.

We proceed as follows. Section II reviews the literature. Section III presents the methodology. Section IV describes the data. Section V presents the analysis. Section VI undertakes an analysis using a firm-bank level matched data set. Section VII concludes.

\section{Literature}

Our paper is related to several strands of the literature. Starting with the work of Peek and Rosengren (1997), several papers studied whether bank supply shocks bring credit provision to a halt in the domestic economy. See for example, Kashyap and Stein (2000), Khwaja and Mian (2008), Paravisini (2008), Schnabl (2012) and Jimenez, Ongena, Peydro-Alcalde, and Saurina (2012). We are interested in the real effects of credit shocks. There are studies that look at the effects of a supply shock to banks on the real aggregate economic activity however, most of these papers use cross-sectional aggregate variation and produce mixed results. Kashyap, Lamont, and Stein (1994) use U.S. manufacturing firms inventory investment data and underline the importance of separating

the "lending story" from the "collateral story" however, the cross-section nature of their dataset does not allow them to do so. Kashyap, Stein, and Wilcox (1993) highlight the change in the firms' composition of financing where firms switched to commercial paper issuance from bank lending as a result of tighter credit conditions. A recent version of this early idea is the work by Adrian, Colla, and Shin (2012) which criticizes the use of aggregate flow-of-funds data and perform the analysis 
using micro level data on loan and bond issuance, showing an increase in bond financing when there is a reduction in bank loan supply.

The evidence on firm level real outcomes is sparse. Two papers using micro-level data with better identification techniques try to link credit shocks to firm level exports, showing sizeable effects. Paravisini, Rappoport, Schnabl, and Wolfenzon (2015), investigate the effect of the 2008 crisis on Peruvian exporters and Amiti and Weinstein (2011) investigate the effect of financial shocks to exporters via trade finance using a bank-firm matched data set from Japan. On investment, Amiti and Weinstein (2013) utilizing the same dataset show that movements in bank loan supply net of borrower characteristics and general credit conditions have large impacts on aggregate loan supply and investment. Duchin, Ozbas, and Sensoy (2010) investigate the effect of the 2008 crisis on corporate investment of U.S. listed firms. This paper shows that firms with more collateral decrease investment less, which is consistent with one of the main results in our paper, showing that firms who suffer from balance sheet weakness decrease investment relatively more $3^{3}$ Acharya, Eisert, Eufinger, and Hirsch (2014) investigates the effects of a shock to GIIPS banks on investment for firms who borrow from GIIPS banks.

None of these papers focus on separating the lending channel from the balance sheet channel and providing estimates for each channel.

\section{Identification}

Our identification strategy is based on a triple differences-in-differences specification. The key justification for this is the ability to control for all the time varying differences between domestic and foreign-owned exporters through the use of foreign-year effects. We focus on the sample of exporting firms because these are the firms who are more likely to experience a positive shock to

\footnotetext{
${ }^{3}$ A similar paper to Duchin, Ozbas, and Sensoy (2010) is the work by Almeida, Campello, Laranjeira, and Weisbenner (2012), where investment outcomes of firms that differ in their long-term debt maturity structure were compared during the 2008 financial crisis.
} 
credit demand as a result of their increased competitiveness due to a depreciated currency. The triple differences-in-differences specification, by interacting foreign ownership with balance sheet weakness and a time dummy that separates the period before and after depreciation and another one that separates the period before and after the twin crisis (depreciation plus banking crisis), will deliver different investment rates of foreign-owned and domestic firms after the depreciation conditional on the fact that both set of firms have the same balance sheet weakness. Such weakness is captured by the share of un-hedged short-term dollar liabilities.

The identifying assumption is that conditional on having a similar balance sheet exposure prior to the crisis, foreign-owned and domestic firms do not differ in any other dimension that is correlated with the difference in their investment rates, before and after the crisis. The only difference between foreign-owned and domestic exporters, both holding un-hedged dollar debt entering the crisis, is the difference in their access to finance before and after the crisis.

We estimate:

$$
\begin{aligned}
y_{i, c, j, t}= & \beta_{1} \text { Foreign }_{i, c, j} \times \text { ShortDollarDebt }_{i, c, j} \times \text { Post }^{\text {currency }_{c, t}} \\
& +\beta_{2} \text { ShortDollarDebt }_{i, c, j} \times \text { Post }^{\text {currency }_{c, t}} \\
& +\beta_{3} \text { Foreign }_{i, c, j} \times \text { ShortDollarDebt }_{i, c, j} \times \text { Post }^{\text {twin }_{c, t}} \\
& +\beta_{4} \text { ShortDollarDebt }_{i, c, j} \times \text { Post }^{\text {twin }_{c, t}} \\
& +\gamma_{F O, t}+\phi_{j, t}+\varphi_{c, t}+\alpha_{i}+\xi_{i, c, j, t}
\end{aligned}
$$

where $y_{i, c, j, t}$ refers to investment of firm $i$, in country $c$, in sector $j$ at time $t$.

Foreign is a dummy variable that takes the value of one if the company is foreign-owned and zero otherwise. This variable is based on the percentage of firm's capital stock held by foreigners (see section 4 for a description of the data). ShortDollarDebt equals one if short term dollar debt 
holdings are higher than the median of the distribution of this variable among firms holding such debt. While using dummy variables might restrict variation for example, in terms of the amount of foreign investment into firms' capital stock, we still prefer the dummy variables for two reasons. First, given our triple interaction specification, indicator variables make the interpretation of the coefficients straightforward by identifying the groups of interest clearly. Second, to avoid concerns about selection into becoming a foreign-owned firm or a high dollar debt holder as a consequence of the crisis, both Foreign and ShortDollarDebt are predetermined variables based on the values of the corresponding variables three years prior to the crisis.

Post $^{\text {twin }}$ is a dummy variable that takes the value of one in the year of the twin crisis and one year after. The corresponding starting depreciation year is 2002 for Argentina and 1995 for Mexico, and in both countries a banking crisis had unraveled just one year prior to the beginning of the currency crisis. Post ${ }^{\text {currency }}$ is a dummy variable that takes the value of one in the year of the currency crisis and one year after, meaning the starting depreciation year is 1999 and 2002 in Brazil (Brazil experienced two different currency crises in a relatively short period of time). See section 4.1 for a description of the crisis episodes.

We include $\phi_{j, t}$ that controls for sector-year fixed effects, $\varphi_{c, t}$ that captures country-year fixed effects, $\gamma_{F O, t}$ are the foreign-year fixed effects, $\alpha_{i}$ are firm-specific effects, and $\xi_{i, c, j, t}$ is the error term 4 By using firm fixed effects we will be identifying solely from firm changes over time. Therefore, since Foreign and ShortDollarDebt are predetermined variables that do not vary over time we cannot identify their main effect which is absorbed by the firm fixed effects. Same is true for the interaction of the two. Country-year and sector-year effects will absorb the effects of any other macroeconomic and industry level shock. Most importantly the foreign-year fixed effects will control for all the time varying differences between foreign-owned and domestic companies.

The interpretation of the coefficients in equation (1) is as follows: $\beta_{2}$ is the effect of holding dollar debt after the currency crisis only for the sample of domestic exporting firms. Similarly, $\beta_{1}$

\footnotetext{
${ }^{4}$ Notice that the Post dummy is captured in the country-year fixed effects as other time dummies.
} 
captures the investment behavior of foreign-owned exporting companies holding dollar debt relative to those domestic-owned exporting companies with dollar debt after the currency crisis. $\beta_{4}$ and $\beta_{3}$ capture similar effects after the twin crisis.

If there is no balance sheet mismatch (when dollar debt is hedged) on the part of both foreignowned and domestic firms, we expect $\beta_{2}$ in equation (1) to be insignificant since domestic exporting firms who hold dollar debt should not perform differently than foreign-owned exporting firms with dollar debt, provided that we have foreign-year fixed effects in the regression controlling for all other differences between foreign-owned and domestic firms. Alternatively, if there is a balance sheet mismatch then both set of exporters will suffer from weak balance sheets, again leading to an insignificant coefficient since there will not be any difference between their performance. The possibility of domestic exporters matching their liability dollarization, while foreign-owned exporters not (or vice versa) that plagued the previous studies is completely accounted for by our triple specification, where we enter the possibility of mismatch explicitly.

Hence, $\beta_{1}$ compared to $\beta_{2}$ and $\beta_{3}$ compared to $\beta_{4}$ is the incremental effect on investment of being a foreign-owned company among exporting firms holding un-hedged dollar debt. If $\beta_{3}>\beta_{4}$ (i.e., foreign-owned exporting firms holding dollar debt outperform domestic exporters holding dollar debt) we interpret this as the "access to finance" effect or evidence for the liquidity channel. This interpretation will be strengthened by $\beta_{1}$ not being statistically different from $\beta_{2}$, during a currency crisis, since domestic banks can still provide credit and the "access to finance" effect should be mitigated (see section 4.1 and figure 3 for a lengthier discussion about this point).

\section{Data and Crises Background}

The empirical analysis draws on a unique database with accounting information for the entire universe of publicly-traded companies in three Latin American countries, spanning the period 1990 
to $20055^{5}$ The countries covered are: Argentina, Brazil and Mexico $6^{6}$ A distinct feature of this dataset is that together with firm level investment, it contains detailed information on the currency and maturity composition of firms' balance sheets, the breakdown of sales into domestic and export revenues, firms' foreign ownership structure and other measures of access to international markets, such as corporate bond issuances abroad at the transaction-level.

The original dataset doest not provide information on firm level ownership and therefore, we undertake a very detailed process to construct a continuous measure of foreign ownership for each firm in our sample. Our indicator of foreign ownership is based on precise dates of ownership changes, foreigner's share in firm's capital stock and the nationality of the parent and global ultimate parent (see section $\mathrm{C}$ in the online appendix for a full description). As a result, the foreign ownership measure can take any value between 0 and 100 and represents the percentage of capital owned by foreign investors at a given point in time. Figure 1 shows the evolution of average foreign ownership over time in our sample, in a balanced panel. Many Latin American countries underwent massive privatization processes during the 1990s. Therefore, as expected, foreign ownership has steadily grown over time. Most of our firms are domestic and hence the distribution of foreign ownership has a high concentration of firms around zero, where 70 percent of the firms are domestic, as shown in panel (a) of figure $2{ }^{7}$ Panel (b) in figure 2 shows that among those firms with positive foreign ownership, 40 percent of the observations are between 85 percent and 100 percent foreign-owned. Hence foreign investors prefer to have a controlling stake in general (or engage in FDI with fully owned subsidiaries). These distributions look similar by country.

\footnotetext{
${ }^{5}$ Section B.1 provides a detail description of the data provider as well as the coverage of the sample. Table A.1 shows the market capitalization of the countries in the analysis together with that of Spain, Germany and US for comparison. Table A.2 shows the average number of listed firms during the period and compares to official sources, reports exit rates and the average number of years. Notice comparison to official sources is not one to one since the World Development Indicators refer to all listed companies while we work with non-financial listed companies.

${ }^{6}$ See the data appendix and Kamil (2009) for a detailed description of the dataset and sources. The original dataset was collected for six countries, Argentina, Brazil, Chile, Colombia, Mexico and Peru, however, only Argentina, Brazil and Mexico experienced currency crises during this period and therefore, we limit the analysis to these three countries. According to Desai, Foley, and Forbes (2008), also Peru experienced a currency crisis in 1993 unfortunately, our data for Peru only starts in 1994 and since we cannot conduct a before/after analysis we do not include Peru in the analysis.

${ }^{7}$ We choose 2000 for being an intermediate year but similar figures are obtained using any other year.
} 


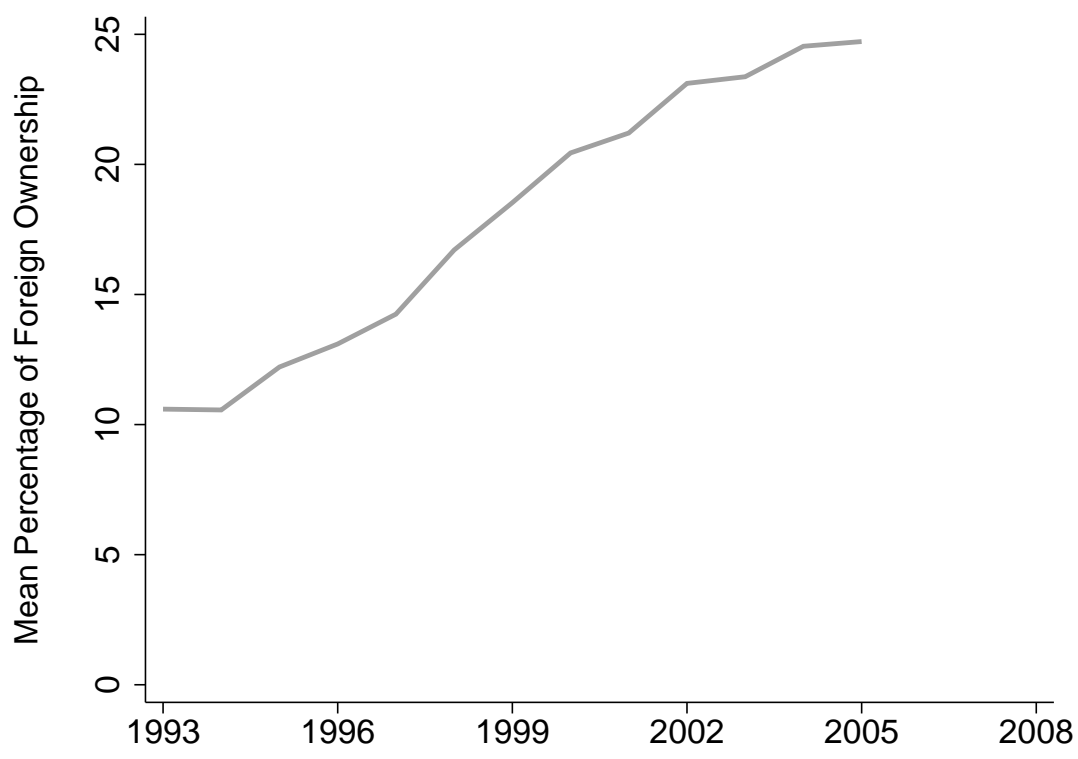

Figure 1: Foreign Ownership Over Time

\subsection{The Crises Episodes}

Table 1 shows the currency crisis and banking crisis episodes for our countries together with percent changes in macro aggregates before, during and after the crisis episodes. All the percent changes in table 1 are averages over two years. As in Desai, Foley, and Forbes (2008) we identify a currency crisis in a given year if the real exchange rate depreciated by more than 25 percent with respect to the previous year. We identify four currency crisis episodes in our sample: Mexico (1995), Brazil (1999), Brazil (2002), and Argentina (2002).8

Following Reinhart and Rogoff (2008) we identify the following banking crises: Argentina (1995) and (2001), Brazil (1995) and Mexico (1994). Reinhart and Rogoff (2008) base their classification of banking crises on two types of events. First, they focus on bank runs that led to the closure, merging,

\footnotetext{
${ }^{8}$ All four episodes imply a considerable depreciation of the real exchange rate: the two episodes in Brazil amounted to a 34 percent depreciation while Mexico witnessed a 47 percent depreciation and Argentina a 96 percent. Notice that Mexico abandoned the peg on December 20th 1994 and we are interested in the effects of such depreciation on investment therefore, we set the beginning of the currency crisis in 1995. To avoid misclassification of companies based on values prior to the crisis, all predetermined variables in Mexico are based on information provided in years 1991, 1992 and 1993.
} 


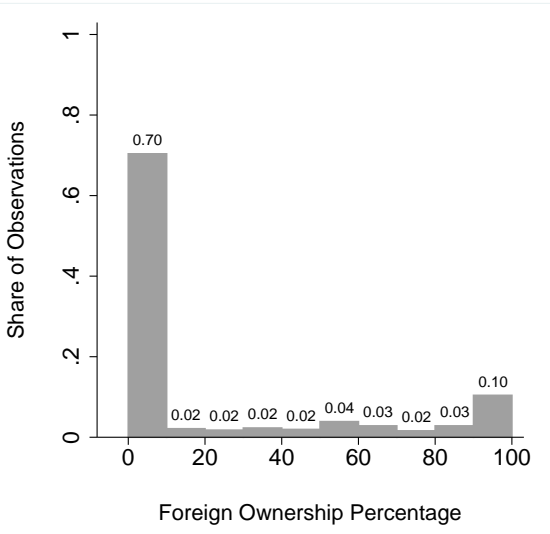

(a) All firms

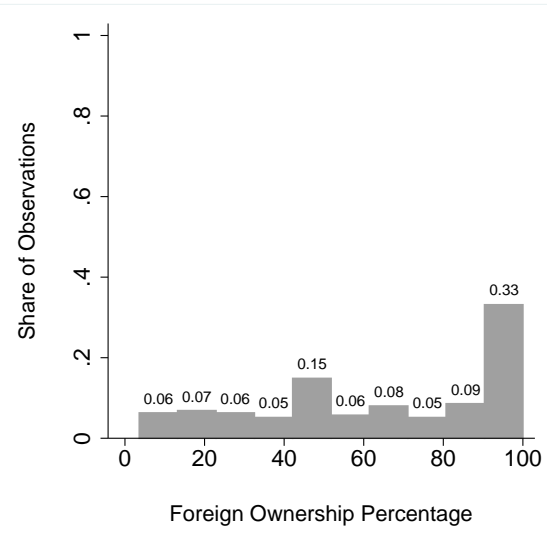

(b) Foreign-Owned firms

Figure 2: Distribution of Foreign Ownership in 2000

Table 1: Macroeconomic Outcomes: Twin and Currency Crises

\begin{tabular}{llllll}
\hline \hline \multirow{2}{*}{ Outcome } & Period & $\begin{array}{l}\text { Argentina } \\
2002\end{array}$ & $\begin{array}{l}\text { Mexico } \\
1995\end{array}$ & $\begin{array}{l}\text { Brazil } \\
1999\end{array}$ & $\begin{array}{l}\text { Brazil } \\
2002\end{array}$ \\
\hline \multirow{2}{*}{ GDP per capita growth } & prior crisis & $-3.7 \%$ & $1.3 \%$ & $0.2 \%$ & $1.3 \%$ \\
& crisis & $-2.5 \%$ & $-2.4 \%$ & $0.8 \%$ & $0.5 \%$ \\
& post crisis & $7.8 \%$ & $4.2 \%$ & $1.3 \%$ & $3.1 \%$ \\
GFKF to GDP & prior crisis & $-12.0 \%$ & $2.7 \%$ & $4.0 \%$ & $2.7 \%$ \\
& crisis & $-6.5 \%$ & $-9.5 \%$ & $-1.8 \%$ & $-5.0 \%$ \\
\multirow{2}{*}{ Trade Balance to GDP } & post crisis & $25.0 \%$ & $14.4 \%$ & $2.7 \%$ & $6.1 \%$ \\
& prior crisis & $1.0 \%$ & $3.9 \%$ & $3.1 \%$ & $11.9 \%$ \\
& crisis & $29.4 \%$ & $24.0 \%$ & $15.7 \%$ & $2.6 \%$ \\
& post crisis & $6.1 \%$ & $1.1 \%$ & $11.9 \%$ & $-0.8 \%$ \\
\hline \hline
\end{tabular}

Notes: Using data on CPI, the real exchange rates were obtained as the deflated end-of period exchange rates. A currency crisis is defined as a 25 percent increase in the real exchange rate relative to the previous year. We identify four depreciation episodes in our sample: Argentina (2002), Mexico (1995), Brazil (1999) and Brazil (2002). Note that Mexico abandoned the peg in December 1994, Brazil in January 1999 and finally, Argentina in January 2002. In addition, following Reinhart and Rogoff (2008) we identify the following banking crises that predated a currency crisis: Argentina (2001) and Mexico (1994). Therefore, there are two twin crises episodes (simultaneous currency and banking crisis) in our sample: Argentina (2002) and Mexico (1995). The figures in the table refer to percentage changes defined over two year. GDP stands for Gross Domestic Product. GFKF to GDP stands for the ratio of Gross Fixed Capital Formation to GDP. Trade Balance to GDP stands for the ratio of Exports minus Import to GDP.

or takeover by the public sector of one or more financial institutions. Second, in the absence of bank runs, a banking crisis involves the closure, merging, takeover, or large-scale government assistance of an important financial institution (or group of institutions) that marks the start of a string of similar outcomes for other financial institutions 9

\footnotetext{
${ }^{9}$ For example, Argentina (2001) and Mexico (1994) were precipitated by different events. In Argentina, in March 2001, a bank run started due to lack of public confidence in government policy actions. There was strong opposition
} 
Table 1 shows that, with the exception of Argentina, the other countries were showing similar rates of GDP growth, investment and trade balance, prior to the crisis. During the crisis and in its aftermath, experiences differ from country to country, showing the importance of including countryyear fixed effects. A common feature of recovery in all countries is the increase in investment and exports leading to a positive trade balance growth.

A critical assumption for our study is that banks are illiquid only during twin crises and not during currency crises. Notice that our results do not rest on the very strict form of this assumption. We only need banks to be relatively more illiquid during twin crises compared to currency crises. Since the seminal work of Kaminsky and Reinhart (1999), there has been an extensive literature highlighting the role of a troubled banking sector that turns a currency crisis into a twin crisis. This is especially relevant for emerging markets where stock and bond markets are less developed and banks are the main source of credit. Therefore, bank illiquidity means a halt in domestic credit provision. Banks can also be insolvent if they have a balance-sheet mismatch of their own. For our purposes of focusing on the real effects of the crisis, where the investment decision is taken by the firm, the key factor is whether or not banks can provide liquidity to firms, regardless of whether they are themselves illiquid or insolvent. The extensive literature on the bank lending channel also provides evidence on the causal link between a negative shock to banks and the credit provision to firms in a developing country context, as reviewed in the related literature section. The relevant aspect for our analysis is that all the banking crises predate the currency crises and were not originated by firm bankruptcy. If banks become insolvent under a currency crisis and halt domestic credit provision as much as in the case of a twin crisis, then our firm-level access

from the public to the new fiscal austerity package sent to the Congress and the amendment to the convertibility law (change in parity from being pegged to the dollar, to being pegged to a basket composed of the US dollar and Euro) as described in Laeven and Valencia (2008). As a result of the bank run, partial withdrawal restrictions were imposed (corralito) and fixed-term deposits (CDs) were reprogrammed to stop outflows from banks (corralon). In Mexico, the 1994 banking crisis had different origins. Until 1991 banks were nationalized. With the privatization process in 1991-1992, investors with scarce previous experience in banking wanting to quickly recover their investment extended large amounts of loans without a proper credit risk analysis. This behavior, together with the stagnation of real estate prices and the increase in US real interest rates eroded banks' balance sheets. In 1994, 9 out of 34 commercial banks were intervened and 11 banks participated in the loan/purchase recapitalization program. These 9 banks accounted for 19 percent of the financial system assets. 
to finance measure -foreign ownership- should not have differential explanatory power among the types of crisis, i.e., domestic firms should do worse than foreign-owned firms under both types of crisis.

Figure 3 demonstrates the case in point and shows that, countries that experienced a twin crisis (Argentina and Mexico) witnessed a significant decline in domestic credit provision starting in the year prior to the currency crisis, whereas this did not happen in Brazil that went through two currency crisis episodes. Figure 3 shows local banks' credit to the private sector (as a percent of GDP). The top panel shows the case of Mexico and Argentina. In Mexico, the banking crisis of 1994 is followed by the currency crisis in 1995. Domestic credit as percent of GDP dropped sharply, corresponding to a 40 percent decline in credit provision to the private sector between 1994 and 1996. In Argentina, the decline in credit as a percentage of GDP was around 50 percent between 2001 and 2003. The lower panel represents Brazil who did not suffer from a collapse in bank lending during the currency crises of 1999 and 200210

\subsection{Descriptive Statistics}

Table 2 reports the percentage of observations by type of firm, averaged over the sample period. Foreign is a dummy that takes the value of one if the company is majority owned (more than 50 percent) by a foreign investor and zero otherwise. Brazil and Mexico show a similar percentage of foreign-owned observations (on average 10 percent) while in Argentina 40 percent of the firms are foreign-owned according to this definition. If we were to focus on the subsample of firms with some foreign ownership, close to 45 percent of Mexican firms with some foreign ownership are majority

\footnotetext{
${ }^{10}$ Notice the beginning of the 90 s was a very turbulent period in Brazil. Inflation was rampant with a peak of 82.4 percent in March 1990. A new government designed a stabilization program, Plano Real, aimed to reduced fiscal deficit and introduced a new currency. During the 1980s, banks acted as intermediaries of the public sector debt and benefited from high inflation and indexation. To avoid reducing their profits once inflation was brought down, banks initially expanded credit (mostly through consumer and commercial loans). Although the new currency brought down inflation, it could not prevent the banking crisis of the mid 90s. According to Reinhart and Rogoff (2008) in 1994, 17 small banks were liquidated, three private banks were intervened, and eight state banks placed under administration. The Central Bank intervened in or put under temporary administration 43 financial institutions. Private banks returned to profitability in 1998, but public banks did not begin to recover until 1999.
} 


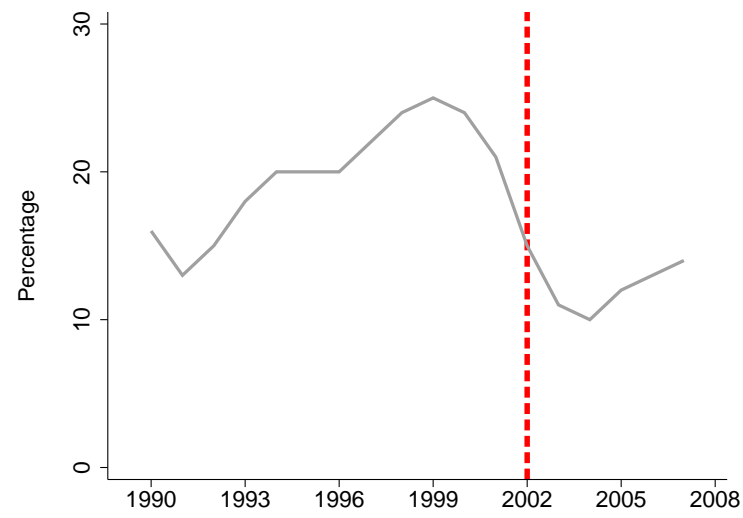

(a) Argentina

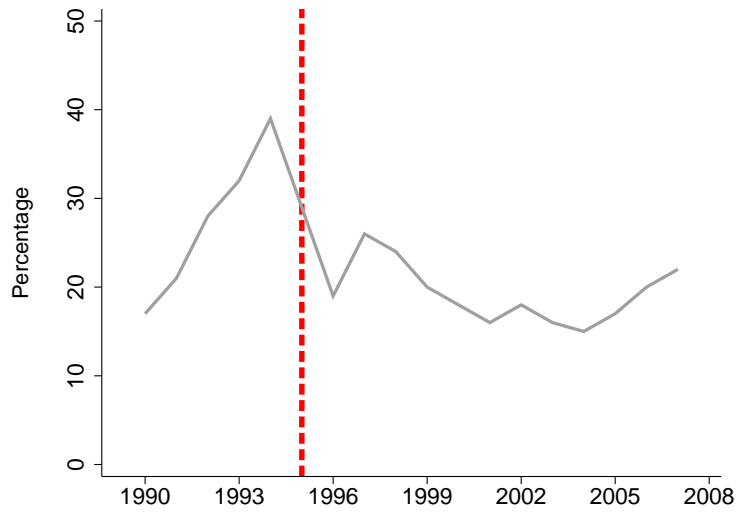

(b) Mexico

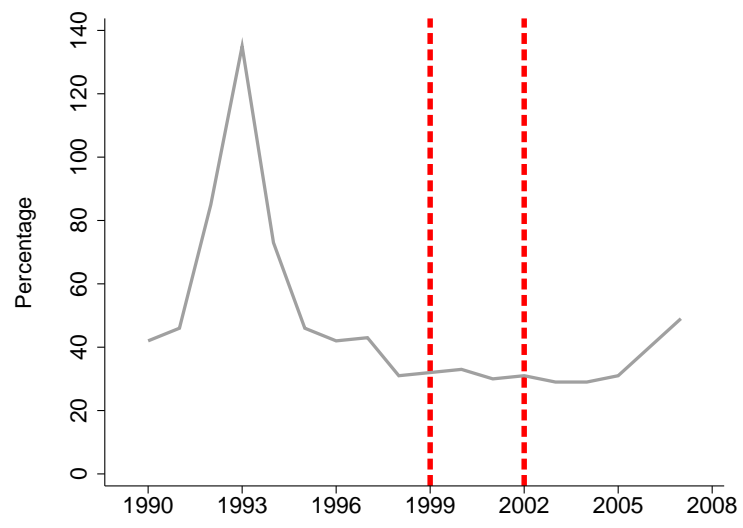

(c) Brazil

Figure 3: Local Banks' Credit to the Private sector as a share of GDP, IFS Database.

Note: The dashed vertical lines indicate the timing of the currency crises. 
owned and in the case of Argentina 67 percent of foreign-owned companies are majority owned. Another important variable in the analysis is export status. Around 58 percent of the observations report some export revenue but only 35 percent of the total observations report a ratio of export revenue to sales greater than 1 percent, captured by the HighExporter variable.

We measure dollar liabilities as the ratio of total dollar liabilities to total liabilities and shortterm dollar liabilities as the ratio of short-term dollar liabilities to total short-term liabilities 1185 percent of the sample reports some positive debt holding denominated in foreign currency while only 56 percent of the sample reports positive dollar assets. Notice although from this table we cannot know the extent of dollar assets, the percentage of observations reporting dollar assets is remarkably higher in Argentina and Mexico compared to Brazil and we will take this into account during our robustness exercises 12

Table 2: Percentage of Observations - By type of Firm and Country

\begin{tabular}{|c|c|c|c|c|c|c|}
\hline & Foreign & Exporter & $\begin{array}{l}\text { High } \\
\text { Exporter }\end{array}$ & $\begin{array}{l}\text { Total } \\
\text { DollarDebt }\end{array}$ & $\begin{array}{l}\text { Short } \\
\text { DollarDebt }\end{array}$ & DollarAssets \\
\hline Argentina & $\begin{array}{l}36.74 \% \\
(577)\end{array}$ & $\begin{array}{l}56.64 \% \\
(572)\end{array}$ & $\begin{array}{l}27.27 \% \\
(572)\end{array}$ & $\begin{array}{l}97.70 \% \\
(564)\end{array}$ & $\begin{array}{l}95.11 \% \\
(225)\end{array}$ & $\begin{array}{l}87.76 \% \\
(572)\end{array}$ \\
\hline Brazil & $\begin{array}{l}12.75 \% \\
(2,000)\end{array}$ & $\begin{array}{l}48.43 \% \\
(1,398)\end{array}$ & $\begin{array}{l}35.34 \% \\
(1,398)\end{array}$ & $\begin{array}{l}75.99 \% \\
(1,749)\end{array}$ & $\begin{array}{l}57.19 \% \\
(1,266)\end{array}$ & $\begin{array}{l}20.61 \% \\
(1,407)\end{array}$ \\
\hline Mexico & $\begin{array}{l}8.07 \% \\
(1,971)\end{array}$ & $\begin{array}{c}66.79 \% \\
(1,963)\end{array}$ & $\begin{array}{l}36.53 \% \\
(1,963)\end{array}$ & $\begin{array}{l}89.44 \% \\
(1,960)\end{array}$ & $\begin{array}{c}88.16 \% \\
(1,960)\end{array}$ & $\begin{array}{l}93.26 \% \\
(846)\end{array}$ \\
\hline Total & $\begin{array}{l}13.76 \% \\
(4,548)\end{array}$ & $\begin{array}{l}58.78 \% \\
(3,933)\end{array}$ & $\begin{array}{l}34.76 \% \\
(3,933)\end{array}$ & $\begin{array}{l}85.02 \% \\
(4,273)\end{array}$ & $\begin{array}{l}77.25 \% \\
(3,451)\end{array}$ & $\begin{array}{l}55.96 \% \\
(2,825)\end{array}$ \\
\hline
\end{tabular}

Notes: The percentages are based on the sample of firms with available information for the variable Investment/Assets t -1 . Foreign is a dummy that equals one if the firms is more than 50 percent foreign-owned. Exporter is a dummy that equal one if the firm reports export revenue. HighExporter is a dummy that equals one if the ratio of exports to sales is greater than 1 percent (corresponds to the 10th percentile of the exports to sales distribution among exporting firms). TotalDollarDebt, ShortDollarDebt and DollarAssets are indicator variables that equal one if the firm reports dollar debt, short-term dollar debt or dollar assets, respectively. Numbers in parenthesis refer to the total number of observations with non-missing values on which the percentages are based.

\footnotetext{
${ }^{11}$ Short-term liabilities refer to outstanding debt that must be paid within 12 months.

${ }^{12}$ In the case of Mexico the sample of firms with available information on dollar assets drops to half so it is not fully comparable.
} 
Table 3 reports the main summary statistics 13 Our measure of investment is the change in the stocks of property, plant and equipment from $t-1$ to $t$ net of depreciation normalized by assets in $t-1$. This is a commonly used measure in the literature. It is the accounting value of the outstanding stock of physical assets. This investment to asset ratio is winsorized at the lower and upper 1 percent level at the country level to control for outliers before it is used in the regressions. The measure might be sensitive to valuation effects so normalizing with assets aims at controlling for the firm specific valuation changes that will arise due to differencing the capital stock. Firm fixed effects help to minimize the effects of accounting bias in the value of capital stock. Finally, country-year fixed effects will account for any changes in the valuation effects that are common to all firms operating in the same country.

On average firms hold 29 percent of their short-term debt denominated in foreign currency while exporters hold on average higher values of their debt denominated in foreign currency (42 percent). Bonds and equity issuance abroad is limited at 3-4 percent and loan issuance abroad is close to 6-8 percent. Online appendix table A.3 shows the corresponding correlations.

What is crucial for this study is the variation in dollar debt holdings across different types of firms. Table 4 shows that on average exporters hold more dollar debt than non-exporting firms. However, what is important for our differences-in-differences methodology is the difference between foreign-owned and domestic exporters, who seem to hold similar average ratios of short-term debt denominated in foreign currency. In the case of Mexico the difference between foreign-owned and domestic exporters is slightly higher however, this difference is not statistically significant in the period prior to the crisis 14

\footnotetext{
${ }^{13}$ The cleaning procedure outlined in the appendix leave us with complete information for an unbalanced panel of 7,255 firm-year observations, which consist of 933 firms with an average of around 7.7 years each. Data on investment and additional controls included later on in the estimation leaves us with a sample of 4,548 observations or 660 firms. Notice some of our main regressions are based on a sample of 2,016 observations or 252 firms. This is the subsample of exporting firms.

${ }^{14}$ On average prior to the crisis, domestic exporters held 58 percent of the short-term debt denominated in dollars while foreign-owned exporter held 50 percent and this difference is not statistically significant. See also table 9 for further robustness regarding different trends in dollar debt holdings between the two groups of interest prior to the crisis.
} 
Table 3: Descriptive Statistics

\begin{tabular}{|c|c|c|c|c|c|c|}
\hline \multirow[t]{2}{*}{ Sample: } & \multicolumn{3}{|c|}{ All } & \multicolumn{3}{|c|}{$\begin{array}{c}\text { HighExporter } \\
\text { holding High Dollar Debt }\end{array}$} \\
\hline & Mean & sd & Obs & Mean & sd & Obs \\
\hline Investment/Assets $t-1$ & 0.00052 & 0.135 & 4548 & 0.007 & 0.147 & 1,295 \\
\hline $\log$ (Assets) & 19.50 & 1.699 & 4548 & 20.02 & 1.668 & 1,295 \\
\hline ShortDollarDebt & 0.293 & 0.286 & 3448 & 0.524 & 0.245 & 1,063 \\
\hline ExportShare & 0.134 & 0.215 & 3933 & 0.245 & 0.247 & 1,251 \\
\hline HighExporter & 0.443 & 0.497 & 4548 & 1 & 0 & 1,295 \\
\hline ForeignShare & 14.13 & 29.90 & 4548 & 15.34 & 31.22 & 1,295 \\
\hline Foreign & 0.125 & 0.331 & 4548 & 0.164 & 0.370 & 1,295 \\
\hline ForeignExporter & 0.034 & 0.182 & 3933 & 0.094 & 0.292 & 1,251 \\
\hline Leverage & 0.478 & 0.202 & 4548 & 0.470 & 0.167 & 1,295 \\
\hline BondAbroad & 0.029 & 0.169 & 4548 & 0.048 & 0.214 & 1,295 \\
\hline InternationalLoan & 0.058 & 0.233 & 4548 & 0.098 & 0.298 & 1,295 \\
\hline EquityAbroad & 0.035 & 0.185 & 4548 & 0.045 & 0.207 & 1,295 \\
\hline
\end{tabular}

Notes: Statistics refer to the final sample of firms used in the estimation. The HighExporter sample is based on a predetermined dummy that equals one if the ratio of exports to sales is greater than 1 percent (corresponds to the 10th percentile of the exports to sales distribution among exporting firms) during the three years prior to the crisis. Those holding HighDollarDebt are based on a predetermined variable that takes the value of one if the ratio of short-term dollar denominated liabilities to total shortterm liabilities is higher than median value of the distribution of firms holding short-term dollar debt and zero otherwise. Investment is physical stock of capital (property, plant and equipment) at time $t$ minus physical stock of capital at time $t-1$ net of depreciation normalized by lagged total assets. ShortDollarDebt is the ratio of short-term dollar denominated liabilities to short-term debt (lagged). ExportShare is the ratio of export revenue to total sales (lagged). HighExporter is a dummy that takes value of one if the ratio of exports to sales is higher than 1 percent at any time during the three years prior to the crisis. ForeignShare is the percentage of capital owned by foreign investors (lagged). Foreign is a dummy that takes the value of one if the share of foreign ownership is more than 50 percent at any time during the three years prior to the crisis. ForeignExporter is a dummy that takes the value of one if the firm is foreign and high exporter at any time during the three years prior to the crisis. Leverage is the ratio of short-term liabilities to short-term assets (lagged). BondAbroad is a dummy that takes the value of one in the year the firm issues a corporate bond abroad (lagged). InternationalLoan is a dummy that takes the value of one in the year the firm issues syndicated loans abroad. EquityAbroad is a dummy that takes the value of one in the year the firm issues equity abroad.

There are certain institutional differences across countries in firms' ability to borrow in foreign currency from local banks. In Argentina and Mexico firms can borrow in dollars from domestic banks. In the case of Brazil, however, most of companies' foreign currency borrowing is obtained abroad (whether bond issuances, bank loans or trade credit). This is because, in Brazil, financial dollarization is severely restricted: on-shore foreign currency deposits are banned and private banks cannot lend in dollars. In Brazil, firms that want to borrow in foreign currency domestically can only do so through the state development bank (BNDES) under stringent conditions. In fact, only exporters can borrow easily from BNDES by pledging foreign currency revenue as collateral 
Table 4: Dollar Debt by Firm Type

\begin{tabular}{|c|c|c|c|c|}
\hline \multirow[b]{2}{*}{$\begin{array}{l}\text { Argentina } \\
\text { Brazil } \\
\text { Mexico }\end{array}$} & \multicolumn{2}{|c|}{ Non-HighExporter } & \multicolumn{2}{|c|}{ HighExporter } \\
\hline & $\begin{array}{l}\text { Mean } \\
0.489 \\
0.133 \\
0.250\end{array}$ & $\begin{array}{l}\text { Median } \\
0.509 \\
0.021 \\
0.161\end{array}$ & $\begin{array}{l}\text { Mean } \\
0.541 \\
0.308 \\
0.554\end{array}$ & $\begin{array}{l}\text { Median } \\
0.611 \\
0.268 \\
0.596\end{array}$ \\
\hline \multirow[t]{2}{*}{$\begin{array}{l}\text { Total } \\
\text { Test Mean Diff (p-value) }\end{array}$} & $\begin{array}{l}0.233 \\
-0.254\end{array}$ & $\begin{array}{l}0.130 \\
(0.000)\end{array}$ & 0.481 & 0.512 \\
\hline & \multicolumn{2}{|c|}{ Domestic } & \multicolumn{2}{|c|}{ Foreign } \\
\hline $\begin{array}{l}\text { Argentina } \\
\text { Brazil } \\
\text { Mexico }\end{array}$ & $\begin{array}{l}\text { Mean } \\
0.482 \\
0.165 \\
0.363\end{array}$ & $\begin{array}{l}\text { Median } \\
0.504 \\
0.040 \\
0.328\end{array}$ & $\begin{array}{l}\text { Mean } \\
0.526 \\
0.137 \\
0.320\end{array}$ & $\begin{array}{l}\text { Median } \\
0.557 \\
0.040 \\
0.296\end{array}$ \\
\hline \multirow[t]{2}{*}{$\begin{array}{l}\text { Iotal } \\
\text { Test Mean Diff (p-value) }\end{array}$} & $\begin{array}{l}0.295 \\
0.019\end{array}$ & $\begin{array}{l}0.218 \\
(0.191)\end{array}$ & 0.276 & 0.195 \\
\hline & \multicolumn{2}{|c|}{ Domestic HighExporter } & \multicolumn{2}{|c|}{ Foreign HighExporte } \\
\hline $\begin{array}{l}\text { Argentina } \\
\text { Brazil } \\
\text { Mexico }\end{array}$ & $\begin{array}{l}\text { Mean } \\
0.507 \\
0.308 \\
0.566\end{array}$ & $\begin{array}{l}\frac{\text { Median }}{0.589} \\
0.265 \\
0.609\end{array}$ & $\begin{array}{l}\text { Mean } \\
0.591 \\
0.309 \\
0.412\end{array}$ & $\begin{array}{l}\frac{\text { Median }}{0.626} \\
0.307 \\
0.439\end{array}$ \\
\hline $\begin{array}{l}\text { Total } \\
\text { Test Mean Diff (p-value) }\end{array}$ & $\begin{array}{l}0.488 \\
0.071\end{array}$ & $\begin{array}{l}0.518 \\
(0.016)\end{array}$ & 0.417 & 0.453 \\
\hline
\end{tabular}

Notes: The table reports the mean and median of the variable ShortDollarDebt in the sample of firms with available investment information. This variable is the ratio of short-term (less than 12 months) dollar denominated liabilities to short-term debt. HighExporter is a dummy variable that takes the value of 1 if the firm reports exports to sales ratio of more than 1 percent and zero otherwise. Foreign is a dummy variable that takes the value of 1 if the firm is more than $50 \%$ owned 
against dollar debt. Given that we will focus on exporters throughout our analysis, the concern that domestic firms in Brazil could hold significantly less foreign currency denominated debt than foreign-owned firms is less troublesome. In fact, as it is clear from the previous table 4, this is not the case. In addition, foreign currency borrowing by domestic firms in Brazil is non-negligible, it amounts to 30 percent of short-term liabilities which is in line with the 40 percent figure for Mexico 15

\section{$5 \quad$ Empirical Analysis}

\subsection{Benchmark Results}

We would like to compare firms with similar balance sheet exposures that only differ in their foreign ownership status. Conditional on the balance sheet channel, the lending channel implies that foreign-owned firms should invest more than domestic firms only during twin crises (when bank liquidity constraints are more pronounced) but no significant differences should be present during currency crises.

We proceed to estimate our main specification lay out in equation (1) on the sample of exporting firms. To define the exporter sample we use a predetermined export dummy. Although changes in export status from non-exporter to exporter at the time of the crisis were relatively limited in our sample and accounted for 4 percent of the exporting observations, we still define an exporter as a firm who reported export revenues during the three years prior to the crisis ${ }^{16}$ To deal with selection concerns, as mentioned above, we also use predetermined dummy variables to measure the exposure

\footnotetext{
${ }^{15}$ Compared to other countries in the region, Brazil's foreign currency borrowing is similar to that in Chile (29 percent) and way higher than the one observed in Colombia where there are also, like in Brazil, controls to foreign currency borrowing (10 percent).

${ }^{16}$ In the case of Argentina, we refer to years 1998, 1999 and 2000; Brazil 1996, 1997 and 1998; Mexico 1991, 1992 and 1993.
} 
of the firm to short-term dollar liabilities ${ }^{17}$ and foreign ownership ${ }^{18}$ There is the possibility that productive firms are bought out by foreigners during the crisis. Aguiar and Gopinath (2005) show that foreign investors buy inferior firms at fire-sale prices. Notice that this mechanism will work against our result but nevertheless, we define foreign status as a dummy based on the ownership status of the firm three years prior to the crisis 19

Table 5 shows our main results. Column (1) shows that foreign-owned exporting companies holding dollar debt increase investment during twin crises relative to domestic firms holding dollar debt. On the contrary, during currency crises there is no significant difference between the investment behavior of foreign-owned and domestic exporters (see column (2)). Column (3) presents the full specification accounting simultaneously for twin and currency crises and corroborating the results shown in columns (1) and (2). As shown in table A.5 in the appendix, results are not driven by entry and exit into the sample and are robust to consider a continuous sample of firms (i.e., firms that we observe from the beginning of the sample to the last year of the crisis, Mexico 1990-1996 and Argentina and Brazil 1993-2003).

To account for the relative importance of holding dollar debt in the overall indebtedness of the company and, also to control for international access to credit other than through foreign ownership, we proceed as follows. First, holding dollar debt might not be an issue for investment if the firm is not leveraged therefore, all specifications include the ratio of total liabilities to total assets lagged one period. Second, we use data from Dealogic Bondware and Loanware to include measures of access to international markets: a BondAbroad dummy that takes the value of one in the year the firm issues a corporate bond abroad, an InternationalLoan dummy that takes the value of one in the year the firm issues a syndicated loan abroad, and an EquityAbroad dummy that takes the

\footnotetext{
${ }^{17}$ ShortDollarDebt is a dummy that equals one if the firm had a ratio of short-term dollar debt to short-term debt greater than 32 percent at any time during the three years prior to the crisis. 32 percent corresponds to the median of the distribution among firms holding short-term dollar debt.

${ }^{18}$ Since we are estimating a triple interaction model to correctly identify the groups of interest we opt for defining foreign-owned companies according to a dummy that equals one if the company is more than fifty percent owned by a foreign investor in the three years prior to the crisis and zero otherwise.

${ }^{19}$ There are 23 cases in which a domestic firms changed ownership status to majority foreign-owned at the time of the devaluation in the total sample, in the exporter sub-sample there are only 6 of such cases.
} 
Table 5: Differential Response of Foreign Exporters holding Dollar Debt during Crises

Dependent Variable: Investment

Sample: Argentina, Mexico and Brazil

(1)

ShortDollarDebt $\times$ Foreign $\times$ Post $^{\text {twin }}$
ShortDollarDebt $\times$ Post $^{\text {twin }}$
ShortDollarDebt $\times$ Foreign $\times$ Post $^{\text {currency }}$
ShortDollarDebt $\times$ Post $^{\text {currency }}$
BondAbroad
InternationalLoan
EquityAbroad

Leverage

Observations

Firm FE

Country-Year FE

Sector-Year FE

Foreign-Year FE

F-test:ShortDollarDebt
(2)

$\begin{array}{lll}0.092^{* *} & & \begin{array}{l}0.089^{* *} \\ (0.04) \\ (0.04)\end{array} \\ -0.100^{* *} & & \begin{array}{l}-0.100^{* *} \\ (0.03)\end{array} \\ (0.03) & & -0.023 \\ & -0.047 & (0.03) \\ & (0.03) & 0.016 \\ & 0.016 & (0.02) \\ & (0.02) & 0.022 \\ 0.022 & 0.024 & (0.02) \\ (0.02) & (0.02) & 0.013 \\ 0.013 & 0.012 & (0.01) \\ (0.01) & (0.01) & 0.004 \\ 0.003 & 0.001 & (0.02) \\ (0.02) & (0.02) & -0.115^{* * *} \\ -0.115^{* * *} & -0.113^{* * *} & (0.03) \\ (0.03) & (0.03) & \end{array}$

$\begin{array}{lll}2,016 & 2,016 & 2,016 \\ & & \\ \text { yes } & \text { yes } & \text { yes } \\ \text { yes } & \text { yes } & \text { yes } \\ \text { yes } & \text { yes } & \text { yes } \\ \text { yes } & \text { yes } & \text { yes }\end{array}$

0.001

0.387

0.008

Notes: Sample of HighExporter. The dependent variable is investment normalized by total assets. Post $^{\text {twin }}$ is a dummy variable that takes the value of one in the year of the twin crisis and one year after, the starting depreciation year is 2002 for Argentina and 1995 for Mexico. Post ${ }^{\text {currency }}$ is a dummy variable that takes the value of one in the year of the currency crisis and one year after, the starting depreciation year is 1999 and 2002 in Brazil. ShortDollarDebt is a predetermined variable that takes the value of one if the ratio of short-term dollar denominated liabilities to total short-term liabilities is higher than median value of the distribution of firms holding short-term dollar debt and zero otherwise. Control variables: Leverage is the ratio of total liabilities to total assets; BondAbroad is a dummy that takes the value of one in the year the firm issues a corporate bond abroad; InternationalLoan is a dummy that takes the value of one in the year the firm issues syndicated loans abroad; EquityAbroad is a dummy that takes the value of one in the year the firm issues equity abroad. All control variables are lagged one period. Standard errors are clustered at the firm-year level. *,** and $* * *$ indicate significance at the $10 \%, 5 \%$ and $1 \%$ levels, respectively. 
value of one in the year the firm issues stock abroad (either as ADR or GDR, whether in the US or other stock market). Although these measures are good proxies for external sources of financing during tranquil times we believe these measures will be relatively weak during financial turbulent times. As argued by the sudden stop literature, markets shy away from emerging markets during such times (see for example Mendoza and Calvo (2000) and Reinhart and Reinhart (2010)). Indeed these measures turn out to be insignificant in all specifications. We thus rely on foreign ownership as a main arms' length source of financing for foreign affiliates located in emerging markets, especially during financial crises 20

In column (3), foreign-owned exporters holding dollar debt increase investment relative to domestic exporters holding dollar debt during twin crises. On the contrary, foreign-owned exporters holding dollar debt do not behave significantly differently than domestic exporters with dollar debt during currency crises. In addition, in column (2), according to the F-test at the end of the table the total effect from dollar debt is not significant during the currency crises years. Results in column (3) indicate that domestic exporters with high levels of short-term dollar debt ratio at the time of the crisis experienced on average an investment ratio that is 10 percentage points lower than that of foreign-owned exporters with high levels of short term dollar debt.

We next turn to analyze the robustness of our results.

\subsection{Additional Controls}

Results in table 5 indicate that controlling for firm balance sheet weakness, during twin crisis, foreign-owned exporters increase investment relative to domestic exporters. Table 6 presents a series of robustness checks based on additional controls.

One of our key assumptions is that firms in countries that experienced a twin crisis cannot

\footnotetext{
${ }^{20}$ Argentina Renault is a case in point. In 2001 , the parent firm contributed $\$ 300$ million to assure the survival of its affiliate. In January 2003 it received an additional $\$ 160$ million from parent Renault to accommodate its bank creditors. The company lost $\$ 71$ million in 2003 and ended the year with debt of about $\$ 276$ million. However, during the first half of 2004, the company made a small profit.
} 
finance investment and/or working capital at the time of the crisis through banks. Several studies have highlighted the dependence of firms on the local banking system in Latin America, such as Demirguc-Kunt and Levine (2001). We add the variable bank debt to total liabilities to control for this effect in column (1). Statistics on this variable are such that, 20 percent of total liabilities correspond to short-term bank debt and exporters seem to exhibit only a slightly higher dependence on short-term bank debt at 22 percent. Highly bank indebted firms tend to invest less and there is no differential effect during the crisis periods, the crucial point is that our main result is not affected.

We have emphasized the role of hard currency denominated income as the main channel to avoid balance sheet mismatches, but there are other factors that can contribute to improve firms' solvency. The potential negative effect of foreign denominated short-term liabilities on firms' balance sheets during crises can be mitigated by significant holdings of foreign currency denominated assets. Column (2) shows that results are robust to controlling for dollar assets as a share of total assets during crises, higher dollar asset holdings on the part of foreign-owned exporters is not the main channel behind their relative better performance. In column (3) we explore another channel that could explain our main results away from an access to credit interpretation: cash holdings. The increase in debt service via the inflated dollar denominated debt would not translate into a balance sheet worsening if firms hold enough cash. Our main results are not affected and foreign-owned companies only have significantly different cash holdings during currency crises.

All the above specifications control for other forms of access to international markets. In column (4) we also test what happens to these other forms of international access to finance at the time of the crisis. Becker and Ivashina (2014) find strong evidence of substitution from loans to bonds at times when bank credit is tight and therefore, if firms could substitute bank credit by corporate bonds at the time of the crisis we should observe no effect on investment. The results in column (4) show that issuing loans and equity abroad at the time of the crisis seems to be negatively correlated with investment. Some of these issuances might be to serve the debt rather than undertake new 
investment projects. What is interesting is that the size of the interaction coefficients decreases which might indicate that foreign-owned firms have access to external as well as internal funding during twin crises.

\subsection{Alternative Explanations}

We have argued that the difference in investment patterns between foreign-owned and domestic exporters during twin crises is due to differences in access to liquidity which we corroborate by the lack of similar findings during currency crises. In this section we explore potential alternative explanations to access to credit. It is important to notice that all specifications include foreign-year fixed effects and therefore, control for systematic differences between foreign-owned and domestic firms. Alternative explanations to the access to credit one have to explain differences between foreign-owned exporters holding un-hedged dollar debt ratios and domestic exporters holding unhedged dollar debt ratios.

It is not straightforward to find alternative explanations to the access to finance reasoning since the alternative explanations would have to apply both to foreign-owned and domestic exporters and also to foreign-owned and domestic exporters with high levels of un-hedged dollar debt. For example, foreign-owned exporters can have better connections or information about international markets; they can export more than domestic exporters to developed countries that are less affected by the crisi ${ }^{21}$ or foreign-owned exporters can rely less than domestic exporters on imported intermediate inputs ${ }^{22}$ All these explanations refer to differences between foreign-owned and domestic

\footnotetext{
${ }^{21}$ Paravisini, Rappoport, Schnabl, and Wolfenzon (2015) show that estimates based on comparing the outcomes of foreign-owned firms and domestic firms might be biased if the crisis had an heterogenous impact across exporters with multiple destinations. If foreign-owned and domestic exporters have clear-cut differentiated markets (i.e., developed countries versus emerging countries' destination markets) the foreign-year fixed effects account for such heterogeneity in destination markets. Therefore, the heterogeneity in destination markets could only bias our estimates if foreignowned exporters holding un-hedged dollar debt export to very different markets than domestic exporters holding un-hedged dollar debt. It is re-assuring that, our twin crises results are based on the experience of Mexico where both foreign-owned and domestic exporters direct over 90 percent of their exports to a single market, the US (see figure A.2 in the appendix). We explore this issue further in table 7.

${ }^{22}$ The depreciation makes the relative price of imports go up which could explain the relatively worst performance of domestic exporters if they are more dependent on imported materials.
} 
Table 6: Differential Response of Foreigner Exporters holding Dollar Debt during Crises: Robustness

Dependent Variable: Investment

Sample: Argentina, Mexico and Brazil

\begin{tabular}{|c|c|c|c|c|}
\hline Robustness Measure & $\frac{\text { BankCredit }}{(1)}$ & $\frac{\text { DollarAss }}{(2)}$ & $\frac{\text { Cash }}{(3)}$ & $\frac{\text { PostCrisis }}{(4)}$ \\
\hline ShortDollarDebt $\times$ Foreign $\times$ Post $^{\text {twin }}$ & $\begin{array}{l}0.089^{* *} \\
(0.04)\end{array}$ & $\begin{array}{l}0.101^{* *} \\
(0.04)\end{array}$ & $\begin{array}{l}0.095^{* *} \\
(0.04)\end{array}$ & $\begin{array}{l}0.071^{* *} \\
(0.04)\end{array}$ \\
\hline ShortDollarDebt $\times$ Post $^{\text {twin }}$ & $-0.104^{* *}$ & $-0.086^{* *}$ & $-0.101^{* *}$ & $-0.082^{* *}$ \\
\hline BankCreditShare & $\begin{array}{l}-0.061^{* *} \\
(0.02)\end{array}$ & & & \\
\hline BankCreditShare $\times$ Post $^{\text {twin }}$ & $\begin{array}{l}0.031 \\
(0.05)\end{array}$ & & & \\
\hline DollarAssets $\times$ Foreign $\times$ Post $^{\text {twin }}$ & & $\begin{array}{l}-0.036 \\
(0.06)\end{array}$ & & \\
\hline DollarAssets $\times$ Post $^{\text {twin }}$ & & $\begin{array}{l}0.015 \\
(0.03)\end{array}$ & & \\
\hline Cash $\times$ Foreign $\times$ Post $^{t w i n}$ & & & $\begin{array}{l}0.017 \\
(0.06)\end{array}$ & \\
\hline Cash $\times$ Post $^{\text {twin }}$ & & & -0.037 & \\
\hline BondAbroad $\times$ Post $^{\text {twin }}$ & & & & $\begin{array}{c}-0.012 \\
(0.10)\end{array}$ \\
\hline InternationalLoan $\times$ Post $^{\text {twin }}$ & & & & $\begin{array}{l}-0.104^{* *} \\
(0.04)\end{array}$ \\
\hline EquityAbroad $\times$ Post $^{\text {twin }}$ & & & & $\begin{array}{l}-0.135^{*} \\
(0.07)\end{array}$ \\
\hline Leverage $\times$ Post $^{\text {twin }}$ & & & & $\begin{array}{l}0.063 \\
(0.07)\end{array}$ \\
\hline BondAbroad & $\mathrm{X}$ & $\mathrm{X}$ & $\mathrm{X}$ & $\mathrm{X}$ \\
\hline InternationalLoan & $\mathrm{X}$ & $\mathrm{X}$ & $\mathrm{X}$ & $\mathrm{X}$ \\
\hline EquityAbroad & $\mathrm{X}$ & $\mathrm{X}$ & $\mathrm{X}$ & $\mathrm{X}$ \\
\hline Leverage & $\mathrm{X}$ & $\mathrm{X}$ & $\mathrm{X}$ & $\mathrm{X}$ \\
\hline Observations & 1,950 & 1,912 & 1,933 & 2,016 \\
\hline Firm FE & yes & yes & yes & yes \\
\hline Country-Year FE & yes & yes & yes & yes \\
\hline Sector-Year FE & yes & yes & yes & yes \\
\hline Foreign-Year FE & yes & yes & yes & yes \\
\hline
\end{tabular}

Notes: Sample of HighExporter. The dependent variable is investment normalized by total assets. Post ${ }^{\text {twin }}$ is a dummy variable that takes the value of one in the year of the twin crisis and one year after, the starting depreciation year is 2002 for Argentina and 1995 for Mexico. Post ${ }^{\text {currency }}$ is a dummy variable that takes the value of one in the year of the currency crisis and one year after, the starting depreciation year is 1999 and 2002 in Brazil. ShortDollarDebt is a predetermined variable that takes the value of one if the ratio of short-term dollar denominated liabilities to total short-term liabilities is higher than median value of the distribution of firms holding short-term dollar debt and zero otherwise. BankCreditShare is the ratio of short-term bank credit to total liabilities. DollarAssets is predetermined variable that takes the value of one if the firm held any dollar denominated assets in the three years prior to the crisis. Cash is a predetermined dummy variable that takes the value of one if the ratio of cash to total assets is higher than the 75 percentile distribution value and zero otherwise. Control variables: Leverage is the ratio of total liabilities to total assets; BondAbroad is a dummy that takes the value of one in the year the firm issues a corporate bond abroad; InternationalLoan is a dummy that takes the value of one in the year the firm issues syndicated loans abroad; EquityAbroad is a dummy that takes the value of one in the year the firm issues equity abroad. All control variables are lagged one period. Standard errors are clustered at the firm level except in column (5) where standard errors are clustered at the firm-year level. *, ** and *** indicate significance at the $10 \%, 5 \%$ and $1 \%$ levels, respectively. 
exporters which we do account for by the inclusion of foreign-year fixed effects. Notice a priori none of these explanations is specific to differences between foreign-owned exporters and domestic exporters with dollar debt 23

One possibility that the foreign-year fixed effects could not rule out is that among firms holding above median dollar debt ratios, foreign-owned companies are larger exporters and therefore, can outperform domestic exporters with lower export shares. Table 7 shows that differences in foreign market exposure cannot explain the increase in investment by foreign-owned companies after the crisis. To proxy the extent of foreign market exposure we take the average of firm exports to sales ratio three years prior to the crisis. First, we show in column (1) that in the sample of exporting firms holding high dollar debt ratios large domestic exporters decrease investment relative to large foreign-owned exporters however, greater foreign exposure by foreign-owned companies is not a significant determinant of investment. Therefore, the increase in investment identified in our main results cannot be explained by a higher export orientation of foreign-owned companies, who also hold high levels of dollar debt. Column (2) shows very similar results in the total sample of exporters and finally, column (3) shows that the decrease in investment by large domestic exporters is mainly explained by these exporters' dollar debt holdings. After accounting for differences in foreign market exposure, foreign-owned firms increase investment relative to domestic exporters holding dollar debt during twin crises as we have found before.

\subsection{Investment trends prior to the crisis}

How different are investment trends for foreign-owned firms with liability dollarization? Although foreign-year effects control for all the time varying differences between foreign-owned exporters and domestic exporters, they do not account for differences between foreign-owned exporters and domestic exporters with dollar debt. One of the main identifying assumptions behind the triple

\footnotetext{
${ }^{23}$ Foreign affiliates import most of their intermediate inputs from the parent company at a lower price or through different trade credit instruments. This will be in line with our thinking that during crises parent companies provide either direct credit to foreign-owned affiliates or indirect credit through cheaper intermediate inputs or trade credit.
} 
Table 7: Foreign Market Exposure and Investment

Dependent Variable: Investment

Sample countries: Argentina, Mexico and Brazil

\begin{tabular}{|c|c|c|c|}
\hline \multirow[t]{2}{*}{ Sample: } & \multirow{2}{*}{$\begin{array}{l}\begin{array}{l}\text { HighExporter } \\
\text { holding }\end{array} \\
\text { ShortDollarDebt } \\
\text { (1) }\end{array}$} & \multicolumn{2}{|c|}{ HighExporter } \\
\hline & & $(2)$ & $(3)$ \\
\hline ExportShare $\times$ Foreign $\times$ Post $^{\text {twin }}$ & $\begin{array}{l}0.294 \\
(0.18)\end{array}$ & $\begin{array}{l}0.209 \\
(0.16)\end{array}$ & $\begin{array}{c}-0.001 \\
(0.22)\end{array}$ \\
\hline ExportShare $\times$ Post $^{t \text { win }}$ & $\begin{array}{l}(0.18) \\
-0.178^{* *} \\
(0.08)\end{array}$ & $\begin{array}{l}(0.10) \\
-0.193^{* *} \\
(0.08)\end{array}$ & $\begin{array}{r}(0.22) \\
-0.133 \\
(0.08)\end{array}$ \\
\hline ShortDollarDebt $\times$ Post $^{\text {twin }}$ & & & $\begin{array}{l}-0.085^{* *} \\
(0.03)\end{array}$ \\
\hline ShortDollarDebt $\times$ Foreign $\times$ Post $^{\text {twin }}$ & & & $\begin{array}{l}0.093^{*} \\
(0.05)\end{array}$ \\
\hline BondAbroad & $\begin{array}{l}0.034 \\
(0.03)\end{array}$ & $\begin{array}{l}0.022 \\
(0.02)\end{array}$ & $\begin{array}{l}0.022 \\
(0.02)\end{array}$ \\
\hline InternationalLoan & $\begin{array}{l}0.010 \\
(0.02)\end{array}$ & $\begin{array}{l}0.006 \\
(0.01)\end{array}$ & $\begin{array}{l}0.012 \\
(0.01)\end{array}$ \\
\hline EquityAbroad & $\begin{array}{l}0.008 \\
(0.03)\end{array}$ & $\begin{array}{l}0.002 \\
(0.02)\end{array}$ & $\begin{array}{l}0.003 \\
(0.02)\end{array}$ \\
\hline Leverage & $\begin{array}{l}-0.112^{* *} \\
(0.04)\end{array}$ & $\begin{array}{l}-0.107^{* * * *} \\
(0.03)\end{array}$ & $\begin{array}{l}-0.112^{* * *} \\
(0.03)\end{array}$ \\
\hline Observations & 1,295 & 2,164 & 2,016 \\
\hline Firm FE & yes & yes & yes \\
\hline Country-Year FE & yes & yes & yes \\
\hline Sector-Year FE & yes & yes & yes \\
\hline Foreign-Year FE & yes & yes & yes \\
\hline
\end{tabular}

Notes: The dependent variable is investment normalized by total assets. ExportShare is the average share of exports to sales ratio three years prior to the crisis. Foreign is a dummy variable that takes the value of one if the firm was majority owned by a foreign investor in that year and zero otherwise. ShortDollarDebt is a predetermined variable that takes the value of one if the ratio of short-term dollar denominated liabilities to total short-term liabilities is higher than median value of the distribution of firms holding short-term dollar debt and zero otherwise. Control variables: Leverage is the ratio of total liabilities to total assets; BondAbroad is a dummy that takes the value of one in the year the firm issues a corporate bond abroad; InternationalLoan is a dummy that takes the value of one in the year the firm issues syndicated loans abroad; EquityAbroad is a dummy that takes the value of one in the year the firm issues equity abroad. All control variables are lagged one period. Standard errors are clustered at the firm level except in column (5) where standard errors are clustered at the firm-year level. $*, * *$ and $* * *$ indicate significance at the $10 \%, 5 \%$ and $1 \%$ levels, respectively. 
difference-in-difference strategy is that both foreign-owned and domestic exporters holding dollar debt had similar investment trends prior to the crisis. We are working with a relatively homogenous sample of firms, they are all listed, with non-negligible export revenue and substantial dollar debt holdings. In addition, the regressions control for a host of other observable characteristics like the leverage ratio, access to international markets, sector-year fixed effects or country-year fixed effects. Therefore, we expect similar investment trends prior to the crisis. In table 8 we conduct a placebo test using years prior to 1995 as the crisis years and we cannot find systematic differences in investment rates between foreign-owned and domestic firms holding above median dollar debt in any year prior to the crisis.

\subsection{Are dollar debt holdings exogenous?}

Our results are based on the assumption that firms across countries freely choose the percentage of their short-term debt that is denominated in foreign currency. We do not want our results to be driven by differences across countries in dollar debt practices. As we explained before most of Brazilian companies foreign currency borrowing is obtained abroad (whether bond issuances or bank loans). Exporters can borrow from the BNDES in foreign currency though. In fact, table 4 shows that although lower than the Argentinean and Mexican levels, short-term dollar debt in Brazil represents on average 30 percent of short-term debt. Most importantly, most of the variation in short-term dollar debt takes place within the sample of exporters (i.e. non-exporting companies do not hold significant amounts of dollar debt) which is our sample of interest given that they are the ones faced with the investment opportunity. Although the median domestic exporter in Brazil holds lower levels of dollar debt than the foreign-owned counterpart, so do Argentinean domestic exporters and it does not seem to be something specific to Brazil.

Finally, it is also possible that both foreign-owned and domestic firms reduce their dollar liabilities in anticipation to the crisis and it might be that foreign-owned exporters predict currency crisis more accurately. This can explain the no-difference result between foreign-owned and do- 
Table 8: Differential Response of Foreign Exporters holding Dollar Debt during Crises: Placebo Test

Dependent Variable: Investment

Sample: Argentina, Mexico and Brazil

(1)

0.085
$(0.13)$
0.051
$(0.05)$








0.005
$(0.03)$
0.012
$(0.02)$
0.005
$(0.02)$
$-0.118^{* * *}$
$(0.04)$
1,647
yes
yes
yes
yes

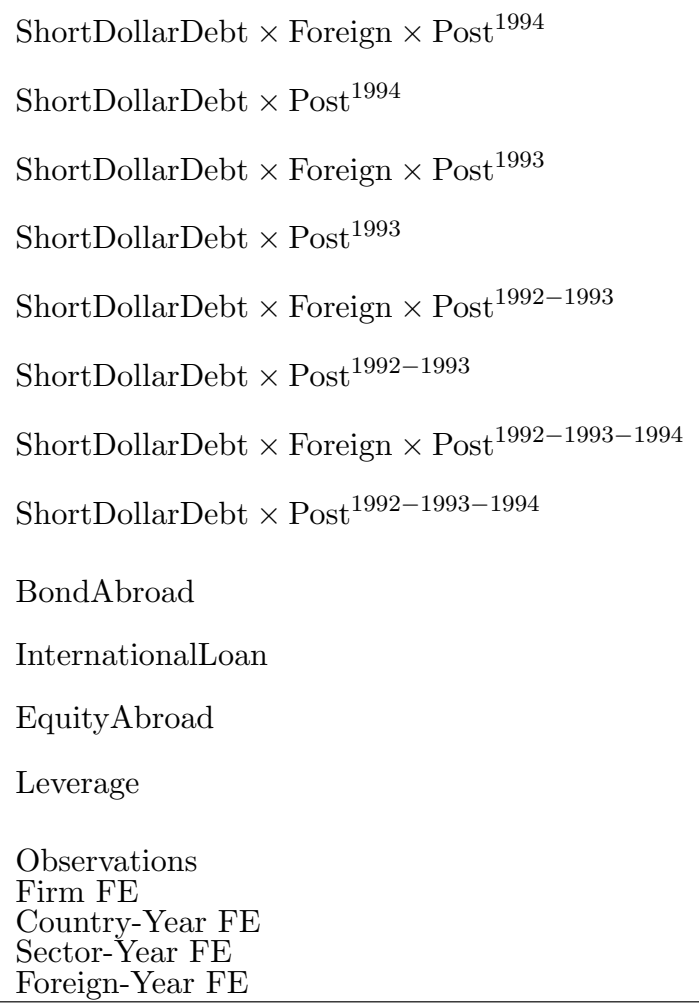

$(2)$

$(3)$

(4)

$\begin{array}{lll}-0.098 & & \\ (0.11) & & \\ 0.050 & & \\ (0.05) & & \\ & -0.120 & \\ & (0.13) & \\ & 0.039 & \\ & (0.06) & \\ & & 0.023 \\ & & (0.09) \\ & & 0.053 \\ & & (0.04) \\ 0.006 & 0.007 & 0.005 \\ (0.03) & (0.03) & (0.03) \\ 0.012 & 0.012 & 0.013 \\ (0.02) & (0.02) & (0.02) \\ 0.004 & 0.004 & 0.004 \\ (0.02) & (0.02) & (0.02) \\ -0.116^{* *} & -0.116^{* *} & -0.118^{* * *} \\ (0.04) & (0.04) & (0.04) \\ 1,647 & 1,647 & 1,647 \\ \text { yes } & \text { yes } & \text { yes } \\ \text { yes } & \text { yes } & \text { yes } \\ \text { yes } & \text { yes } & \text { yes } \\ \text { yes } & \text { yes } & \text { yes } \\ & & \end{array}$

Notes: The dependent variable is investment normalized by total assets. Post ${ }^{\text {twin }}$ is a dummy variable that takes the value of one in the year of the twin crisis and one year after, the starting depreciation year is 2002 for Argentina and 1995 for Mexico. Post ${ }^{\text {currency }}$ is a dummy variable that takes the value of one in the year of the currency crisis and one year after, the starting depreciation year is 1999 and 2002 in Brazil. ShortDollarDebt is a predetermined variable that takes the value of one if the ratio of short-term dollar denominated liabilities to total short-term liabilities is higher than median value of the distribution of firms holding short-term dollar debt and zero otherwise. Control variables: Leverage is the ratio of total liabilities to total assets; BondAbroad is a dummy that takes the value of one in the year the firm issues a corporate bond abroad; InternationalLoan is a dummy that takes the value of one in the year the firm issues syndicated loans abroad; EquityAbroad is a dummy that takes the value of one in the year the firm issues equity abroad. All control variables are lagged one period. Standard errors are clustered at the firm level except in column (5) where standard errors are clustered at the firm-year level. *, ** and *** indicate significance at the $10 \%, 5 \%$ and $1 \%$ levels, respectively. 
Table 9: Dollar Debt prior to the Crisis: Foreign and Domestic Exporters

\begin{tabular}{llll}
\hline \hline Dependent Variable: Share of Short-term Dollar Debt in Short-term Debt & \\
\hline Sample Countries: & $\begin{array}{l}\text { Mexico } \\
1990-1994 \\
\text { Sample Years: }\end{array}$ & $\begin{array}{l}\text { Brazil } \\
1993-1994 \\
(1)\end{array}$ & $\begin{array}{l}\text { Argentina } \\
1993-2000 \\
(3)\end{array}$ \\
& & & \\
Foreign & 0.104 & -0.045 & -0.032 \\
& $(0.09)$ & $(0.08)$ & $(0.12)$ \\
BondAbroad & 0.058 & 0.166 & $-0.206^{*}$ \\
& $(0.05)$ & $(0.19)$ & $(0.11)$ \\
InternationalLoan & -0.026 & 0.111 & -0.014 \\
& $(0.06)$ & $(0.14)$ & $(0.09)$ \\
EquityAbroad & 0.041 & 0.127 & $-0.159^{* *}$ \\
Leverage & $(0.06)$ & $(0.12)$ & $(0.06)$ \\
& -0.231 & -0.115 & 0.609 \\
Observations & $(0.20)$ & $(0.12)$ & $(0.54)$ \\
Firm FE & 428 & 193 & 72 \\
Country-Year FE & yes & yes & yes \\
Sector-Year FE & yes & yes & yes \\
Foreign-Year FE & yes & yes & yes \\
no
\end{tabular}

Notes: The dependent variable is the share of short-term dollar debt in total short-term debt. Foreign is a dummy variable that takes the value of one if the firm was majority owned by a foreign investor in that year and zero otherwise. Control variables: Leverage is the ratio of total liabilities to total assets; BondAbroad is a dummy that takes the value of one in the year the firm issues a corporate bond abroad; InternationalLoan is a dummy that takes the value of one in the year the firm issues syndicated loans abroad; EquityAbroad is a dummy that takes the value of one in the year the firm issues equity abroad. All control variables are lagged one period. Standard errors are clustered at the firm level except in column (5) where standard errors are clustered at the firm-year level. ${ }^{*}, *$ and ${ }^{* * *}$ indicate significance at the $10 \%, 5 \%$ and $1 \%$ levels, respectively.

mestic exporting firms in the case of currency crises. Table 9 shows that there were no systematic differences in dollar debt holdings among foreign-owned and domestic exporters prior to the crisis in each of the countries of interest. 


\section{$6 \quad$ Firm-Bank Level Credit Supply Shock}

Until now, we have used two variables to measure a credit supply shock. One measure is the country-level banking crisis, assuming all banks got hit by a supply shock. The second measure, is based on the firm-level distinction between foreign and domestic ownership. We assume foreignowned firms will be less affected by a domestic banking crisis than domestic firms and hence, they will experience a relatively lower credit supply shock. None of these variables will measure the firm idiosyncratic bank supply shock and therefore, our measure for the lending channel may not be accurate. In the first part of the paper we claim that foreign ownership is a good proxy for access to credit during crises and we have rule out different alternative explanations. In this part of the paper we would like to provide further evidence that substantiates this point. We provide evidence that shows how foreign-owned firms are less sensitive than domestic firms to the credit supply channel.

In this section we employ a new data set from Mexico to measure the firm specific bank supply shock. The data set is similar to credit registry data in that we know the loan amount of each firm from each bank (where the bank can be a domestic Mexican bank or a foreign-owned bank). In fact, the data set provides all sources of financing by the firm not necessarily only banks, financial institutions other than banks are also recorded. The advantage of the data set is to have a firm specific measure of the bank supply shock and hence, to provide an exact measure of the bank lending channel. Since we have multiple firms (foreign and domestic) borrowing from the same bank, we can trace the differential effect of a bank specific shock on foreign-owned and domestic firms. The main disadvantage is that the data set is only for Mexico during the recent period of 2005-2012 and therefore, we will capture the global financial crisis as the source of the bank credit supply shock instead of Mexico's own peso crisis as we did in the previous section. The second disadvantage is that supply and demand for credit do not move in opposite directions given the lack of a large depreciation.

The purpose of this section is to study the potential differential response of foreign-owned and 
domestic firms to a bank credit supply shock. To proxy the bank credit supply shock we use bank level variation and test whether banks with headquarters in developed countries reduced credit more than domestic (Mexican) or emerging markets banks. The recent financial crisis originated in September 2008 in the US and soon expanded to European countries. Hence, credit provided by local banks to the private sector in Mexico did not experience a major change during this period (see figure A.1 in the appendix). We expect firms that were more dependent on US and European ("Western") banks to face a lower credit supply compared to firms borrowing from Mexican banks. ${ }^{24}$

The identification strategy follows Khwaja and Mian (2008) and Jimenez, Ongena, PeydroAlcalde, and Saurina (2012), where firms borrowing from multiple banks as in the former, eliminate the influence of the firm specific characteristics and controlling for firm-year fixed effects in all specifications, as in the latter, eliminates the time varying changes in demand for credit. We estimate the following equation:

$$
\begin{aligned}
\log \left(C_{i, b, t}\right) & =\beta_{1} \text { WesternBank }_{i, b}+\beta_{2}\left(\text { WesternBank }_{i, b} \times \text { Post }_{t}\right)+ \\
& +\alpha_{i, t}+\delta_{b}+u_{i, b, t}
\end{aligned}
$$

where $C_{i, b, t}$ stands for loans from bank $b$ to firm $i$ at time $t$; Post $t_{t}$ is a dummy variable that takes the value of one in year 2009 and thereafter ${ }^{25}$ WesternBank $_{i, b}$ is a predetermined dummy variable that takes the value of one if firm $i$ borrowed from a western bank $b$ one year prior to the beginning of the crisis (i.e., year 2007) ${ }^{26}$ The firm-time dummies $\alpha_{i, t}$ absorb all changes in credit demand by the firm including all other non-credit shocks to the firm, including common shocks to all firms

\footnotetext{
${ }^{24}$ We use banks for brevity but as we explained before all financial institutions granting credit to these firms are recorded.

${ }^{25}$ We have data available for the period 2005-2012 and we drop the year 2008 from the analysis since some of the balance sheet items refer to only the first three quarters of 2008.

${ }^{26}$ We define Western banks as those whose ultimate owner is headquartered in Austria, Belgium, Switzerland, Germany, Spain, Finland, France, UK, Ireland, Italy, Netherlands, Norway, Sweden, Portugal, Canada, Japan and US.
} 
at time $t$, and $\delta_{b}$ accounts for changes in credit supply that are bank specific and do not vary over time (i.e., certain banks might have more lenient policies than others).

Results from estimating equation (2) are presented in table 10. Column (1) shows that on average Western banks provide higher credit than Mexican or other emerging market's banks during "normal" times ${ }^{27}$ However, the negative interaction term indicates that Western banks decreased credit during the recent global financial crisis. It could be that the decline in credit by foreign banks is not the result of lower liquidity on the part of banks but rather lower demand on the part of firms given the uncertainty conditions. Controlling for firm-year fixed effects rules out this possibility. Similarly, including bank fixed effects guarantees that results are not driven by average differences across banks. Most importantly starting in column (2) all specifications control for firm-bank specific effects, $\delta_{i b}$, that control for potential special firm-bank relations that do not vary over time. Columns (3) and (4) show that both foreign-owned and domestic firms are subject to the credit supply channel. All firms borrowing from Western banks prior to the crisis experienced a decrease in bank credit from those banks.

Columns (5) to (8) explore potential differences in credit patterns according to maturity. In general, comparing the short-term and the long-term results it is clear that most of the decline in total bank credit was due to a decline in short-term bank credit. Both foreign-owned and domestic firms experienced a similar decline in short-term bank credit while domestic firms experienced a sharper decline in long-term bank credit from Western banks.

Results in table 10 indicate that firms that borrowed from Western banks prior to the crisis experienced a decrease in bank credit from these banks during the crisis years. However, total bank credit of the firm does not necessarily need to decrease if firms manage to substitute bank credit across banks. We are interested in analyzing whether firms that were highly exposed to foreign bank credit prior to the crisis witnessed a higher decrease in overall bank credit relative to firms

\footnotetext{
${ }^{27}$ Notice we identify over 400 financial institutions granting credit to firms operating in Mexico. There are only close to 40 banks registered in Mexico. The difference in the number of observations comes from: looking at all financial institutions operating in Mexico (not only banks) so export development agencies or mortgage financial institutions are also considered and; many of these companies borrow from banks operating abroad.
} 
Table 10: Transmission of Credit Shocks by Foreign Banks

Dependent Variable: $\log \left(C_{i, b, t}+1\right)$

\begin{tabular}{|c|c|c|c|c|c|c|c|c|}
\hline \multirow[b]{2}{*}{ Sample } & \multicolumn{4}{|c|}{ TOTAL CREDIT } & \multicolumn{2}{|c|}{ SHORT-TERM } & \multicolumn{2}{|c|}{ LONG-TERM } \\
\hline & $\begin{array}{l}\text { ALL } \\
(1)\end{array}$ & $\begin{array}{l}\text { ALL } \\
(2)\end{array}$ & $\begin{array}{l}\text { FO } \\
(3)\end{array}$ & $\begin{array}{l}\text { DO } \\
(4)\end{array}$ & $\begin{array}{l}\text { FO } \\
(5)\end{array}$ & $\begin{array}{l}\text { DO } \\
(6)\end{array}$ & $\begin{array}{l}\text { FO } \\
(7)\end{array}$ & $\begin{array}{l}\text { DO } \\
(8)\end{array}$ \\
\hline WesternBank $\times$ Post & $\begin{array}{l}-1.704^{* * *} \\
(0.163)\end{array}$ & $\begin{array}{l}-1.704^{* * *} \\
(0.163)\end{array}$ & $\begin{array}{l}-1.508^{* * *} \\
(0.280)\end{array}$ & $\begin{array}{l}-1.777^{* * *} \\
(0.198)\end{array}$ & $\begin{array}{l}-1.006^{* * *} \\
(0.257)\end{array}$ & $\begin{array}{l}-0.907^{* * *} \\
(0.159)\end{array}$ & $\begin{array}{c}-0.506^{*} \\
(0.260)\end{array}$ & $\begin{array}{l}-1.140^{* * *} \\
(0.185)\end{array}$ \\
\hline WesternBank & $\begin{array}{l}2.454^{* * *} \\
(0.134)\end{array}$ & & & & & & & \\
\hline Observations & 10,101 & 10,101 & 2,513 & 7,588 & 2,512 & 7,586 & 2,511 & 7,586 \\
\hline Firms & 123 & 123 & 25 & 98 & 25 & 98 & 25 & 98 \\
\hline Banks & 434 & 434 & 194 & 355 & 194 & 355 & 194 & 355 \\
\hline $\mathrm{R}^{2}$ & .3 & .57 & .55 & .57 & .51 & .5 & .55 & .56 \\
\hline Firm-Year FE & yes & yes & yes & yes & yes & yes & yes & yes \\
\hline Firm-Bank FE & no & yes & yes & yes & yes & yes & yes & yes \\
\hline Cluster & $\begin{array}{l}\text { firm- } \\
\text { bank }\end{array}$ & $\begin{array}{l}\text { firm- } \\
\text { bank }\end{array}$ & $\begin{array}{l}\text { firm- } \\
\text { bank }\end{array}$ & $\begin{array}{l}\text { firm- } \\
\text { bank }\end{array}$ & $\begin{array}{l}\text { firm- } \\
\text { bank }\end{array}$ & $\begin{array}{l}\text { firm- } \\
\text { bank }\end{array}$ & $\begin{array}{l}\text { firm- } \\
\text { bank }\end{array}$ & $\begin{array}{l}\text { firm- } \\
\text { bank }\end{array}$ \\
\hline
\end{tabular}

Notes: The dependent variable $\log \left(C_{i, b, t}+1\right)$ is the $\log$ of bank debt from bank $b$ to firm $i$ at time $t$ plus one. Columns (1) to (4) refer to total bank credit, columns (5) and (6) include short-term bank credit and finally, columns (7) and (8) explore long-term bank credit. $F O$ refers to the sample of foreign-owned firms and $D O$ refers to the sample of domestic firms. WesternBank is a dummy that takes the value of one if the firm was borrowing from a Western bank in year 2007. Columns (3), (5) and (7) present results for the sub-sample of predetermined foreign-owned firms (those firms that were foreign-owned in 2007) while columns (4), (6) and (8) do so for the sub-sample of domestic firms. Standard errors clustered at the firm-bank level are in parenthesis. $* * *, * *, *$, denote significance at $1 \%, 5 \%$, and $10 \%$ levels.

that were less dependent on foreign bank credit prior to the crisis. To explore this possibility we estimate the following regression:

$$
\log \left(C_{i, t}\right)=\beta_{0}+\beta_{1}\left(\text { BankCredit }_{i}{ }^{\mathrm{WB}} \times \text { Post }_{t}\right)+\alpha_{i}+\delta_{t}+u_{i, t}
$$

where $C_{i, t}$ stands for total bank credit of firm $i$ at time $t$ (summing the credit from all the banks); 
Post $_{t}$ is a dummy variable that takes the value of one in years 2009, 2010, 2011 and 2012. We define the variable BankCredit ${ }_{i}{ }^{\mathrm{WB}}$ as the share of Western bank credit in total bank credit in year 2007.

$$
\text { BankCredit }_{i}^{\mathrm{WB}}=\frac{\Sigma_{i} C_{i, b} \times \mathrm{WesternBank}_{i, b}}{\Sigma_{i} C_{i, b}}
$$

Given the different results found for short-term and long-term bank specific credit in table 10 we also explore the possibility that there are differences in total short-term and long-term bank credit at the firm level depending on how exposed firms are to short-term foreign bank credit or long-term foreign bank credit in 2007 prior to the crisis.

$$
\begin{array}{cl}
\text { STBankCredit }_{i}^{\mathrm{WB}}=\frac{\Sigma_{i} S T C_{i, b} \times \mathrm{WesternBank}_{i, b}}{\Sigma_{i} S T C_{i, b}} \quad S T C_{i, b}: \text { short-term bank credit } \\
\text { LTBankCredit }_{i}^{\mathrm{WB}}=\frac{\Sigma_{i} L T C_{i, b} \times \mathrm{WesternBank}_{i, b}}{\Sigma_{i} L T C_{i, b}} \quad L T C_{i, b}: \text { long-term bank credit }
\end{array}
$$

Table 11 presents the main results. We are interested in the differential impact of the credit supply channel for domestic and foreign-owned firms. Columns (1) and (2) show that domestic firms are more exposed to the credit channel relative to foreign-owned firms. Total bank credit of foreign-owned firms heavily borrowing from Western banks prior to the crisis did not change in the crisis years which suggest that foreign-owned firms managed to substitute the decrease in credit by Western banks. On the contrary, domestic firms with high dependence on foreign bank credit prior to the crisis experienced a decline in overall bank credit. Comparing columns (3) and (5) it becomes apparent that most of the decline in total bank credit was driven by lower short-term lending.

It is now clear from tables 10 and 11 that foreign-owned firms are less sensitive to the bank 
Table 11: Transmission of Credit Shocks by Foreign Banks - Firm Level Credit

Dependent Variable: $\log \left(C_{i, t}+1\right)$

\begin{tabular}{|c|c|c|c|c|c|c|}
\hline \multirow[b]{2}{*}{ Sample } & \multicolumn{2}{|c|}{ TOTAL CREDIT } & \multicolumn{2}{|c|}{ SHORT-TERM } & \multicolumn{2}{|c|}{ LONG-TERM } \\
\hline & $\begin{array}{l}\mathrm{DO} \\
(1)\end{array}$ & $\begin{array}{l}\text { FO } \\
(2)\end{array}$ & $\begin{array}{l}\mathrm{DO} \\
(3)\end{array}$ & $\begin{array}{l}\text { FO } \\
(4)\end{array}$ & $\begin{array}{l}\mathrm{DO} \\
(5)\end{array}$ & $\begin{array}{l}\text { FO } \\
(6)\end{array}$ \\
\hline BankCredit ${ }^{W B} \times$ Post & $\begin{array}{l}-0.643^{* *} \\
(0.288)\end{array}$ & $\begin{array}{l}0.763 \\
(0.531)\end{array}$ & & & & \\
\hline STBankCredit ${ }^{W B} \times$ Post & & & $\begin{array}{l}-1.403^{* * *} \\
(0.414)\end{array}$ & $\begin{array}{l}-0.928 \\
(0.714)\end{array}$ & & \\
\hline LTBankCredit $^{\mathrm{WB}} \times$ Post & & & & & $\begin{array}{l}-0.617 \\
(0.463)\end{array}$ & $\begin{array}{l}-0.355 \\
(0.868)\end{array}$ \\
\hline Observations & 478 & 144 & 478 & 144 & 478 & 144 \\
\hline $\mathrm{R}^{2}$ & .87 & .68 & .71 & .68 & .75 & .57 \\
\hline Firm FE & yes & yes & yes & yes & yes & yes \\
\hline Year FE & yes & yes & yes & yes & yes & yes \\
\hline Cluster & firm-year & firm-year & firm-year & firm-year & firm-year & firm-year \\
\hline
\end{tabular}

Notes: The dependent variable $\log \left(C_{i, t}+1\right)$ is the $\log$ of bank debt from bank of firm $i$ at time $t$ plus one. Columns (1) and (2) refer to total bank credit, columns (3) and (4) include short-term bank credit and finally, columns (5) and (6) explore long-term bank credit. FO refers to the sample of foreign-owned firms and $D O$ refers to the sample of domestic firms. BankCredit ${ }^{\mathrm{WB}}$ is the share of foreign bank credit to total bank credit in 2007. STBankCredit ${ }^{W B}$ is the share of foreign short-term bank credit to short-term bank credit in 2007. LTBankCredit ${ }^{W B}$ is the share of foreign long-term bank credit to long-term bank credit in 2007. is a dummy that takes the value of one if the firm was borrowing from a Western bank in year 2007. Columns (2), (4) and (6) present results for the sub-sample of predetermined foreign-owned firms (those firms that were foreign-owned in 2007) while columns (1), (3) and (5) do so for the sub-sample of domestic firms. Standard errors clustered at the firm-year level are in parenthesis. ***, ${ }^{* *}$, $*$, denote significance at $1 \%, 5 \%$, and $10 \%$ levels.

credit channel supporting the evidence presented in the first part of the paper. In there, we showed that in the face of a country wide credit supply shock foreign-owned firms, as opposed to domestic firms, increased investment rates. The firm-bank matched data in this section allows to confirm that in addition, given a bank specific supply shock, foreign-owned firms are better able to substitute credit across banks and therefore, less exposed to credit supply shocks. 


\section{Conclusion}

We exploit a unique quasi-natural experiment, the experience of Latin American countries with a plethora of financial crises during 1990-2005, in order to disentangle and quantify the effects of the lending channel and the balance sheet channel on corporate investment.

A currency crisis constitutes a positive credit demand shock for exporting firms. These firms may want to increase investment in order to export more through a competitive devaluation, however, they may not be able to do so if they are credit constrained. In this setting, credit constraints can take different forms. First, the depreciated currency is a negative shock to the firms' collateral in the presence of currency and maturity mismatches, compromising firms' solvency. Second, even if firms do not become credit constrained due to the devaluation, and they enjoy strong balance sheets,

they might still not exploit the investment opportunity resulting from a depreciated currency if simultaneously, there is a credit crunch in the economy due to a banking crisis. Emerging markets firms heavily rely on their local banks for external financing and experience a severe halt in liquidity during banking crises.

In order to separate the collateral hypothesis from the liquidity hypothesis, we compare firms with similar net worth at the onset of a financial crisis that differ on their ability to overcome the liquidity crunch of local banks. We condition on the balance sheet weakness and then, we study the sensitivity of investment by foreign-owned and domestic exporters to the negative credit supply shock that occurs during a banking crisis, where we expect the former group to be less credit constrained. We test this assumption using firm-bank matched data from Mexico. Our identification strategy is a triple differences-in-differences where we interact foreign ownership with balance sheet weakness before and after, both twin and currency crises. This strategy allow us to control all possible time varying differences between foreign-owned and domestic exporters by saturating the regression with a full set of foreign-year fixed effects.

We find that there is no difference in the investment behavior of foreign-owned exporters rel- 
ative to domestic exporters under a currency crisis. This means they both utilize the investment opportunity regardless of their balance sheet weakness. If the currency crisis occurs simultaneously with the banking crisis, on the other hand, foreign-owned exporters perform significantly better. They increase investment ratios by 7 percent and domestic exporters decrease investment by 13 percent. Overall, our results suggest that the key factor hindering investment in the aftermath of financial crises is illiquidity.

Some caveats are in order. The focus of the paper is on exporting firms that the trade literature extensively shows are of higher quality than other firms in the corporate sector. Therefore, the results presented here cannot be generalized to the full economy. In fact, results indicate that currency mismatches are especially detrimental for local firms with no investment opportunities. Future research needs to focus on the full set of firms, where the balance sheet channel will clearly be very important for firms operating in the non-tradeable sector. 


\section{References}

Acharya, V., T. Eisert, C. Eufinger, and C. Hirsch (2014): "Real Effects of the Sovereign Debt Crisis in Europe: Evidence from Syndicated Loans," CEPR Working Paper, DP10108.

Adrian, T., P. Colla, And H. Shin (2012): "Which Financial Frictions? Paring the Evidence from Financial Crisis of 2007-9," Forthcoming in NBER Macroeconomic Annual.

Aguiar, M. (2005): "Investment, Devaluation, and Foreign Currency Exposure: The Case of Mexico," Journal of Development Economics, 78, 95-113.

Aguiar, M., and G. Gopinath (2005): "Fire-sale FDI and Liquidity Crises," Review of Economics and Statistics, 87(3), 439-452.

Allen, M., C. Rosenberg, C. Keller, B. Setser, and N. Roubini (2002): "Nonmonetary Effects of the Financial Crisis in Propagation of the Great Depression," IMF Working Paper, (210).

Almeida, H., M. Campello, B. Laranjeira, and S. Weisbenner (2012): "Corporate Debt Maturity and the Real Effects of the 2007 Credit Crisis," Critical Finance Review, 1(1), 3-58.

Amiti, M., And D. Weinstein (2011): "Exports and Financial Shocks," Quarterly Journal of Economics, 126(4), 1841-1877.

- (2013): "How Much Do Bank Shocks Affect Investment? Evidence From Maatched BankFirm Loan Data," NBER working paper, (18890).

Becker, B., And V. Ivashina (2014): "Cyclicality of credit supply: Firm level evidence," Journal of Monetary Economics, 62(C), 76-93.

Bleakley, H., and K. Cowan (2008): "Corporate Dollar Debt and Depreciations: Much Ado About Nothing?," Review of Economics and Statistics, 90(4), 612-626. 
Demirguc-Kunt, A., And R. Levine (2001): "Bank-Based and Market-Based Financial Systems: Cross-Country Comparisons," in Financial Structure and Economic Growth: A Cross-Country Comparison, ed. by A. Demirguc-Kunt, and R. Levine. Cambridge, MA: MIT Press.

Desai, M. A., C. F. Foley, and J. R. Hines (2004): "A Multinational Perspective on Capital Structure Choice and Internal Capital Markets," Journal of Finance, 59(6), 2451-2487.

Desai, M. A., F. C. Foley, and K. J. Forbes (2008): "Financial Constraints and Growth: Multinational and Local Firm Responses to Currency Depreciations," Review of Financial Studies, 21(6), 2857-2888.

Duchin, R., O. Ozbas, and B. A. Sensoy (2010): "Costly external finance, corporate investment, and the subprime mortgage crisis," Journal of Financial Economics, 97, 418-435.

Jimenez, G., S. Ongena, J. Peydro-Alcalde, and J. Saurina (2012): "Credit Supply: Identifying Balance-Sheet Channels with Loan Applications and Granted Loans," American Economic Review, 102(5), 2301-2326.

KAmiL, H. (2009): “A new database on currency and maturity composition of firms' balance sheets in Latin America: 1992-2005," International Monetary Fund, Washington.

Kaminsky, G. L., and C. M. Reinhart (1999): "The Twin Crises: The Causes of Banking and Balance-of-Payments Problems," American Economic Review, 89(3), 473-500.

Kashyap, A., O. Lamont, and J. Stein (1994): "Credit Conditions and the Cyclical Behavior of Inventories," Quarterly Journal of Economics, 109(3), 565-592.

Kashyap, A., And J. Stein (2000): "What Do A Million Observations on Banks Say About the Transmission of Monetary Policy?," American Economic Review, 90(3), 407-428.

Kashyap, A., J. Stein, and D. W. Wilcox (1993): "Monetary Policy and Credit Conditions: Evidence from the Composition of External Finance," American Economic Review, 83(1), 78-98. 
Khwaja, A. I., And A. Mian (2008): "Tracing the Impact of Bank Liquidity Shocks: Evidence from an Emerging Market," American Economic Review, 98(4), 1413-1442.

Mendoza, E. G., And G. A. Calvo (2000): "Capital-Markets Crises and Economic Collapse in Emerging Markets: An Informational-Frictions Approach," American Economic Review, 90(2), $59-64$.

Paravisini, D. (2008): "Local Bank Financial Constraints and Firm Access to External Finance," Journal of Finance, 63(5), 2160-2193.

Paravisini, D., V. Rappoport, P. Schnabl, and D. Wolfenzon (2015): "Dissecting the Effect of Credit Supply on Trade: Evidence from Matched Credit-Export Data," The Review of Economic Studies, 82(1), 333-359.

Peek, J., And E. Rosengren (1997): "The International Transmission of Financial Shocks: The Case of Japan," American Economic Review, 87(4), 495-505.

Reinhart, C. M., and V. R. Reinhart (2010): "Capital Flow Bonanzas," NBER ISOM.

Reinhart, C. M., And K. S. Rogoff (2008): "Banking Crises: An Equal Opportunity Menace," NBER Working Paper, (14587).

(2010): "Growth in a Time of Debt," American Economic Review, 100(2), 573-578.

Schnabl, P. (2012): "Financial Globalization and the Transmission of Bank Liquidity Shocks: Evidence from an Emerging Market," Journal of Finance, 67(3), 897-932. 


\section{Online Appendix (not for publication)}

\section{A Interpretation of the triple interaction: time-varying depen- dent variables}

In what follows we first, describe the variables used in the specification and then explain the interpretation of the coefficients.

$$
\begin{aligned}
y_{i, c, j, t}= & \beta_{1} \text { Foreign }_{i, c, j, t-1} \times \text { SDDebt }_{i, c, j, t-1} \times \text { Post }_{c, t} \\
& +\beta_{2} \text { Foreign }_{i, c, j, t-1} \times \text { SDDebt }_{i, c, j, t-1} \\
& +\beta_{3} \text { Foreign }_{i, c, j, t-1} \times \text { Post }_{c, t} \\
& +\beta_{4} \text { SDDebt }_{i, c, j, t-1} \times \text { Post }_{c, t} \\
& +\beta_{5} \text { Foreign }_{i, c, j, t-1} \\
& +\beta_{6} \text { SDDebt }_{i, c, j, t-1} \\
& +\phi_{j, t}+\varphi_{c, t}+\alpha_{i}+\xi_{i, c, j, t}
\end{aligned}
$$

where $y_{i, c, j, t}$ refers to investment of firm $i$, in country $c$, in sector $j$ at time $t$.

Foreign can be used as a continuous variable in lagged form or as a dummy that takes the value of one if the company is foreign-owned and zero otherwise ${ }^{28}$ SDDebt measures lagged short-term dollar denominated liabilities. Post is the depreciation dummy and equals to one in the year of currency crisis and one year after ${ }^{29}$ We include $\phi_{j, t}$ that controls for sector-year fixed effects, $\varphi_{c, t}$

\footnotetext{
${ }^{28}$ This variable is based on the percentage of firm's capital stock held by foreigners (see section III for a description of the data). It is worth noting at this stage that while using dummy variables might restrict variation in terms of amount of foreign investment into firms' capital stock, given the triple interaction specification, indicator variables make the interpretation of the coefficients straightforward by identifying the groups of interest clearly.

${ }^{29}$ Investment responds with a lag and hence we follow the literature on defining this dummy over the crisis and the
} 
that captures country-year fixed effects, $\alpha_{i}$ are firm-specific effects, and $\xi_{i, c, j, t}$ is the error term ${ }^{30}$ By using firm fixed effects we will be identifying solely from firm changes over time. Country-year and sector-year effects will absorb the effects of any other macroeconomic and industry level shock.

The triple interaction turns out to be crucial for identification. To see why, we compare the interpretation of the coefficients in equation (1) to those that would result from estimating the following equation, which for completeness we will also present in our empirical section:

$$
\begin{aligned}
y_{i, c, j, t}= & \beta_{3} \text { Foreign }_{i, c, j, t-1} \times \text { Post }_{c, t} \\
& +\beta_{4} \text { SDDebt }_{i, c, j, t-1} \times \text { Post }_{c, t} \\
& +\beta_{5} \text { Foreign }_{i, c, j, t-1} \\
& +\beta_{6} \text { SDDebt }_{i, c, j, t-1} \\
& +\phi_{j, t}+\varphi_{c, t}+\alpha_{i}+\xi_{i, c, j, t}
\end{aligned}
$$

In equation (1), $\beta_{4}$ is the effect of holding dollar debt after the crisis only for the sample of domestic exporting firms. This is not the case for $\beta_{4}$ in equation (2) since now this coefficient reflects a combined effect of foreign-owned and domestic exporting firms. Similarly, $\beta_{3}$ in equation (1) captures the investment behavior of foreign-owned exporting companies with no dollar debt relative to those foreign-owned exporting companies with dollar debt at the time of the crisis, $\beta_{1}$. Compared to equation (2) the advantage is that the coefficient $\beta_{3}$ in equation (1) does not confound the effect of foreign-owned exporting companies holding and not holding dollar debt as it would be the case of the coefficient $\beta_{3}$ in equation (2).

If exporting firms match their dollar debt holdings with export revenue and there are no other following year. We check this assumption by defining the dummy over two and three years obtaining similar results. ${ }^{30}$ Notice that the Post dummy is captured in the country-year fixed effects as other time dummies. 
difference between foreign and domestic exporters, we expect $\beta_{4}$ in equation (1) to be insignificant since domestic exporting firms who hold dollar debt should not perform differently than foreignowned exporting firms with dollar debt. We expect them both to have strong balance sheets as a result of offsetting their dollar debt risk with export revenue. Alternatively, if there is no such matching then both set of exporters will suffer from weak balance sheets, again leading to an insignificant coefficient since there will not be any difference between their performance. The key point is that the possibility of domestic exporters matching their liability dollarization, while foreign-owned exporters not (or vice versa) is completely accounted for by the triple specification. Hence, $\beta_{1}$ compared to $\beta_{4}$ is the incremental effect on investment of being a foreign-owned company among exporting firms holding dollar debt. If $\beta_{1}>\beta_{4}$ (i.e., foreign-owned exporting firms holding dollar debt outperform domestic exporters holding dollar debt) we interpret this as the "access to finance" effect or evidence for the liquidity channel. Both foreign-owned and domestic exporting firms experience a similar change in their net worth but foreign-owned exporting firms manage to increase investment relative to domestic exporting firms. This means that there is something different about foreign-owned exporting firms with dollar debt at the time of the crisis. Our interpretation of this difference is access to external funds. The potential finding $\beta_{1}<\beta_{3}$ (i.e., foreign-owned exporting firms with dollar debt underperforming relative to foreign-owned exporters without dollar debt holdings) would highlight the importance of insolvency since compared to firms that have the best access to liquidity (i.e., foreign-owned companies), those with a deterioration in their balance sheet would underperform.

To summarize, if both foreign-owned and domestic exporters with dollar debt holdings can avoid a mismatch on their balance sheet and hence insolvency, then the differential response between the two captures access to liquidity. This result should only hold when domestic companies suffer from a liquidity problem. Hence, we should see foreign-owned exporters with dollar debt investing more relative to domestic exporters with dollar debt holdings only under twin crises. This can only be done by means of a triple interaction rather than a double interaction that would mask the groups 
of interest. Same reasoning applies when both set of exporters are not matching currency and maturity composition of their liabilities to their income/assets, or even more importantly one set of exporters avoid a mismatch while the other ones do not. A double interaction as in equation (2) will be open to these possibilities. In that case, where balance sheet channel is not explicitly accounted for, the difference between the two set of exporters cannot be attributed to the lending channel.

\section{B Variable explanations and sources}

Financial statement data was obtained from annual balance sheet reports drawn from local stock markets and regulatory agencies in each country. Data on foreign currency liabilities and assets (and their maturity structure) was hand-collected from the financial explanatory notes of firms' balance sheets and includes several maturities. These are all assets or liabilities outstanding which are denominated in -or indexed to- foreign currency, issued domestically or abroad. In the case of liabilities, these include bank loans, commercial debt, trade credit and foreign securities. Foreign currency assets include cash, government securities indexed to the dollar, bank deposits abroad and overseas client credits.

While firms in many cases report both consolidated and unconsolidated financial statements, we use unconsolidated figures, to reduce variations arising from changes in subsidiaries' ownership and to avoid double counting. Information on firms' export revenues was obtained from income statement data. When this was not available, we used countries' customs office records or Central Bank's Balance of Payments trade registries. In the latter case, we merged balance sheet information with firms' export sales using their tax code identifier and/or name.

The issuance data is at transaction-level and obtained from Dealogic database and includes firms' bond and syndicated loan issuance.

Investment is measured as the stock of physical capital. The stock of physical capital, in turn, 
is defined as the sum of expenditures on property, plant, equipment, plus technical reappraisal (valuation change), minus cumulated depreciation.

\section{B.1 Data Sources}

We cover the universe of non-financial listed companies in the countries under analysis. The data provider is Economatica which is a company founded in 1986, that focuses on the collection and management of high-reliability databases, as well as the continued development of high-performance analytic tools. Through their system they offer information on the capital markets of the major economies of Latin America and the United States. In their local offices, they collect data and assist analysts from Brazil, Mexico, Chile, Peru, Argentina and Colombia.

Economatica is used by thousands of analysts at numerous financial institutions around the world, such as fund management, pensions, brokerage firms, investment banks, investor relations departments, wealth-management, private-banking, family-office, consulting, academic institutions, and others. They use databases and information coming from reliable sources. They only work with the primary data sources and official providers of information (ANBIMA, BMF\&BOVESPA, CVM) or their equivalent organizations in the countries they cover. As a result, Economatica can offer the most reliable and complete set of information for the region. They collect balance sheet information on all listed companies in the region. Table A.1 shows the market capitalization of all listed companies as a percentage of GDP in our sample of countries as well as in the US, Spain and Germany for comparison.

As previously noted we only work with non-financial corporations and therefore, we cannot directly compare to official sources since they report the total number of listed companies. However, in table A.2 we attempt to give an overview of the coverage of the dataset. Panel A compares the number of firms in Economatica to that reported by the World Development Indicators and although not one to one comparable due to the different types of companies included in each database it is clear the good coverage of the dataset. Panel B reports the percentage change in the number of 
Table A.1: Market capitalization of listed companies (\% of GDP)

\begin{tabular}{|c|c|c|c|c|c|c|}
\hline & Argentina & Brazil & Mexico & United & Spain & Germany \\
\hline 1990 & 2.3 & 3.6 & 12.4 & $\begin{array}{l}\text { States } \\
51.2\end{array}$ & 20.7 & 20.1 \\
\hline 1991 & 9.8 & 10.5 & 31.2 & 66.2 & 25.7 & 21.1 \\
\hline 1992 & 8.1 & 11.6 & 38.2 & 68.7 & 15.7 & 16.4 \\
\hline 1993 & 18.6 & 22.7 & 39.9 & 74.7 & 22.8 & 22.4 \\
\hline 1994 & 14.3 & 34.6 & 24.7 & 69.3 & 29.3 & 21.3 \\
\hline 1995 & 14.6 & 19.2 & 26.4 & 89.5 & 32.3 & 22.3 \\
\hline 1996 & 16.4 & 25.8 & 26.8 & 104.7 & 37.9 & 26.8 \\
\hline 1997 & 20.2 & 29.3 & 32.6 & 131.4 & 49.3 & 37.2 \\
\hline 1998 & 15.2 & 19.1 & 18.3 & 148.0 & 65.2 & 48.8 \\
\hline 1999 & 29.6 & 38.8 & 26.6 & 172.2 & 68.2 & 65.2 \\
\hline 2000 & 58.4 & 35.1 & $\begin{array}{l}20.0 \\
18.3\end{array}$ & 146.9 & 84.7 & 65.2 \\
\hline 2001 & 71.6 & 33.6 & 17.4 & 130.4 & 74.8 & 55.0 \\
\hline 2002 & 101.4 & 24.6 & 13.9 & 101.1 & 65.9 & 33.3 \\
\hline 2003 & 30.0 & 42.5 & 17.2 & 123.9 & 80.1 & 43.1 \\
\hline 2004 & 25.3 & 49.8 & 22.3 & 133.0 & 87.9 & 42.4 \\
\hline 2005 & 27.6 & 53.8 & 27.6 & 129.6 & 83.0 & 42.7 \\
\hline 2006 & 30.1 & 65.3 & 36.0 & 140.2 & 104.6 & 54.6 \\
\hline 2007 & 26.3 & 100.3 & 38.1 & 137.8 & 121.7 & 61.3 \\
\hline 2008 & 12.9 & 35.6 & 21.2 & 79.7 & 57.9 & 29.6 \\
\hline 2009 & 12.9 & 72.0 & 38.0 & 104.6 & 86.5 & 38.0 \\
\hline 2010 & 13.8 & 72.1 & 43.2 & 114.5 & 81.8 & 41.9 \\
\hline 2011 & 7.8 & 49.6 & 34.9 & 100.8 & 69.0 & 31.6 \\
\hline 2012 & 5.7 & 54.7 & 44.3 & 115.5 & 73.4 & 42.1 \\
\hline
\end{tabular}

Notes: Market capitalization (also known as market value) is the share price times the number of shares outstanding. Listed domestic companies are the domestically incorporated companies listed on the country's stock exchanges at the end of the year. Listed companies does not include investment companies, mutual funds, or other collective investment vehicles. Source: World Development Indicators: Standard \& Poor's, Global Stock Markets Factbook and supplemental S\&P data.

firms pre- and post-crisis in our sample countries. Finally, Panel $\mathrm{C}$ reports the average number of years we observe each firm, before and after the cleaning procedure (see the next subsection for a description of the cleaning steps).

\section{B.2 Cleaning Steps}

We start by checking basic reporting mistakes in our main variables of interest: SALES: We drop observations if sales are equal to zero.

TOTAL ASSETS: We drop observations if total assets are equal to zero.

DOLLAR LIABILITIES: We drop observations if total dollar liabilities exceed total liabilities. 
Table A.2: Coverage in Terms of Number of Firms

Panel A: Average number of firms in the period up to 2005

\begin{tabular}{llll}
\hline \hline & Argentina & Brazil & Mexico \\
\hline World Development Indicators & 128 & 471 & 183 \\
Economatica & 77 & 336 & 168 \\
percentage & $60 \%$ & $71 \%$ & $92 \%$ \\
\hline \hline
\end{tabular}

Panel B: Percentage Change in the number of firms

\begin{tabular}{llll}
\hline \hline & Argentina & Brazil & Mexico \\
\hline & & & \\
Period & $2000-2003$ & $1998-2003$ & $1993-1996$ \\
Economatica & $-14 \%$ & $-15 \%$ & $-21 \%$ \\
& & & \\
\hline \hline
\end{tabular}

Panel C: Average Number of Years

\begin{tabular}{llll}
\hline \hline & Argentina & Brazil & Mexico \\
\hline & & & \\
Economatica Raw data & 11.4 & 8.3 & 7.5 \\
Economatica After cleaning & 10.8 & 7.7 & 7.2 \\
\hline \hline
\end{tabular}

Notes: Panel A reports the number of firms over the corresponding sample period (1993-2005 for Argentina and Brazil and 1990-2005 for Mexico) reported in the World Development Indicators (WDI) and in our dataset. In the WDI listed domestic companies are the domestically incorporated companies listed on the country's stock exchanges at the end of the year. This indicator does not include investment companies, mutual funds, or other collective investment vehicles. Economatica number of listed companies refers to non-financial corporations. Panel B reports the percentage change in the number of firms before and after the crisis in our sample of firms. Panel C reports the average number of years of firms in the panel. 
DOLLAR ASSETS: We drop observations if total dollar assets exceed total assets.

SHORT DOLLAR LIABILITIES: We drop observations if short dollar liabilities exceed total liabilities or short-term liabilities.

LONG DOLLAR LIABILITIES: We drop observations if long dollar liabilities exceed total liabilities or long-term liabilities.

CASH: We drop observations if negative values of cash or cash is greater than total assets.

BANK DEBT: We drop observations if bank debt is greater that total liabilities. EXPORTS: We drop observations if the value of exports is greater than total sales.

Then we look at basic ratios: sales to total assets, liabilities to total assets and we drop observations at the 1 and 99 percentile of the distribution. To ensure that results are not driven by outliers, we then dropped all firm/year observations for explanatory variables that exceeded the sample mean by more than five standard deviations. We compute the change in total assets, sales and physical capital stock and construct a Z-score using the sample mean and standard deviation for each country/year. We drop firm/year observations that have absolute value of $\mathrm{Z} i$. Finally, we winsorize by country at the 1 and 99 percentile value the investment variable.

\section{Foreign Ownership Variable}

To identify the ownership structure of each firm in our sample and track their changes over time, we proceed in two steps. First, we gathered data on all cross-border Mergers and Acquisitions (M\&A) of Latin-American firms between 1981 to 2005 using the SDC Platinum database from Thompson (for the period 1981 to 2001) and Zephyr from Bureau Van Dijk (from 1997 to 2005). We then identified all transactions where the target involved a firm in our sample. Examining M\&As from the 1980s onwards ensures that we capture any change in ownership relationship that predates the firm's first appearance in our sample, that is 1990. For each deal, we obtained the date on which the transaction became effective and characteristics of the target and acquiring firms, in 
particular, the nationality of the target and acquiring firm, and that of the acquiror's ultimate parent. The database also includes transaction-specific information on percent of shares acquired and the percent of shares owned before and after the transaction was completed. In total, we consider 4,406 completed deals that resulted in a change in majority control in a target firm in our sample as well as acquisitions of minority stakes (some of which involve multiple acquisitions of the same target). Of the firms in our sample, 28 percent were involved in at least one M\&A during the period. For each firm involved in an M\&A, we constructed a continuous, time-varying measure of foreign ownership based on the percentage fraction of shares held by foreign and domestic investors in each year.

Second, there might be ways other than M\&As for foreign investors to invest in firms. Foreign ownership acquisitions can arise by means of IPOs, venture capital activity, or private equity deals, which are not covered in M\&As hence in our procedure. In some cases, foreign-owned firms could have been established before 1980, and not involved in a M\&A since then. To remedy this, we used the Corporations Affiliations database to identify Latin American firms in our sample that are affiliates, subsidiaries and/or divisions of global multinational firms. This database contains international public and private business profiles and corporate linkage ("who owns whom") for approximately 184,000 public and private companies worldwide.

Finally, notice that in addition to the "formal" sources of foreign ownership data we checked firm by firm company's history ${ }^{31}$ After this extensive search of all these alternative sources, if we find no evidence of foreign ownership we assume the company is domestic.

We construct a continuous, time-varying measure of foreign ownership based on the percentage fraction of shares held by foreign and domestic investors in each year. For example, the M\&A databases would identify an M\&A transaction where a foreign company that already owned 50 percent of a company in a target country, buys 10 percent more of that company. Our foreign

\footnotetext{
${ }^{31}$ We doubled checked with various internet resources, including the information provided by the company on its own web page and that of the Funding Universe website (www.fundinguniverse.com/company-histories/) that provides information on companies' history as well as press articles of the time.
} 
ownership variable would be 50 until the time of the transaction and 60 thereafter. In the case where we had more than one foreign investor in the same year we faced the problem of not knowing if the foreign companies were buying from each other, from other domestic investors, or rather directly from the target company. In those cases we checked the company history profile, the Funding Universe website and other specialized newspaper information. In the rare case that information was not available, we decided on a conservative measure of foreign ownership and assumed that the foreign companies bought from each other. We then merged this information with annual balance sheet data. In the few cases of target firms being renamed after the acquisition, we kept the old id number rather than creating a new company after the M\&A.

\section{Tables}




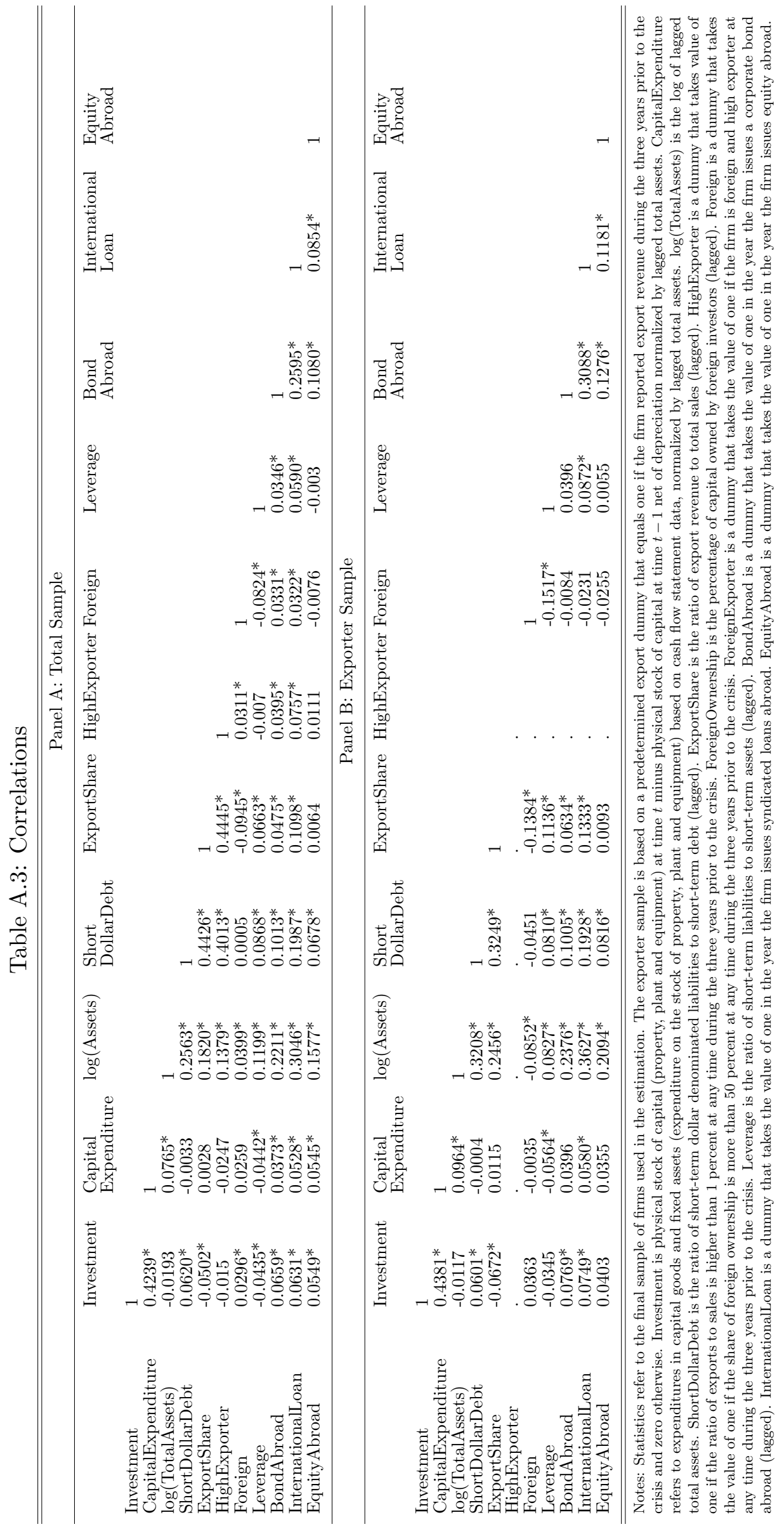


Table A.4: Differential Response of Foreigners in the Sample of Solvent Firms

Dependent Variable: Investment

Sample: Argentina, Mexico and Brazil

Sub-Sample: Solvent Firms

(1)

$$
\begin{aligned}
& 0.073^{* *} \\
& (0.03) \\
& -0.035 \\
& (0.02)
\end{aligned}
$$

Foreign $\times$ Post $^{\text {currency }}$

$\ln ($ FOshare +1$)$

$\ln ($ FOshare +1$) \times$ Post $^{\text {twin }}$

$\ln ($ FOshare +1$) \times$ Post $^{\text {currency }}$

BondAbroad

InternationalLoan

EquityAbroad

Leverage

Observations

Firm FE Country-Year FE Sector-Year FE
$(2)$

$\begin{array}{ll}0.089 & 0.049 \\ (0.06) & (0.05) \\ 0.158^{* *} & 0.267^{* *} \\ (0.07) & (0.12) \\ -0.012 & -0.058 \\ (0.06) & (0.07) \\ 0.009 & -0.031 \\ (0.04) & (0.09) \\ 0.033 & 0.024 \\ (0.02) & (0.03) \\ 0.009 & 0.004 \\ (0.03) & (0.06) \\ -0.076^{*} & 0.097 \\ (0.05) & (0.08)\end{array}$

$(0.04) \quad(0.05)$

430

$\begin{array}{lll}1,122 & 1,122 & 430 \\ & & \\ \text { yes } & \text { yes } & \text { yes } \\ \text { yes } & \text { yes } & \text { yes } \\ \text { yes } & \text { yes } & \text { yes }\end{array}$

Notes: The dependent variable is investment normalized by total assets. Post ${ }^{\text {twin }}$ is a dummy variable that takes the value of one in the year of the twin crisis and one year after, the starting depreciation year is 2002 for Argentina and 1995 for Mexico. Post ${ }^{\text {currency }}$ is a dummy variable that takes the value of one in the year of the currency crisis and one year after, the starting depreciation year is 1999 and 2002 in Brazil. The sample of firms with no mismatch (solvent firms) is defined based on whether $\frac{\text { Exports-ShortDollarLiab }}{\text { Assets }} \geq 0$ in the two years prior to the crisis. Column (3) reports the results for the subsample of solvent firms that reported some foreign ownership in any year. Foreign is a predetermined variable that takes the value of one if the firm is foreignowned in the two years prior to the crisis and zero otherwise. FOshare is a continuous foreign ownership variable so that equals the percentage of foreign ownership divided by one hundred. Control variables: Leverage is the ratio of total liabilities to total assets; BondAbroad is a dummy that takes the value of one in the year the firm issues a corporate bond abroad; InternationalLoan is a dummy that takes the value of one in the year the firm issues syndicated loans abroad; EquityAbroad is a dummy that takes the value of one in the year the firm issues equity abroad. All control variables are lagged one period. Standard errors are clustered at the firm-year level. *, ** and $* * *$ indicate significance at the $10 \%, 5 \%$ and $1 \%$ levels, respectively. 
Table A.5: Foreign Exporters holding Dollar Debt during Crises: Sample of Permanent Firms

Dependent Variable: Investment

Sample: Argentina, Mexico and Brazil
$0.134^{* *}$
$(0.05)$
$-0.163^{* * *}$
$(0.05)$

ShortDollarDebt $\times$ Post $^{\text {twin }}$

ShortDollarDebt $\times$ Foreign $\times$ Post $^{\text {currency }}$

ShortDollarDebt $\times$ Post ${ }^{\text {currency }}$

BondAbroad

InternationalLoan

EquityAbroad

Leverage

Observations

Firm FE

Country-Year FE

Sector-Year FE

Foreign-Year FE

F-test:ShortDollarDebt
(1)

(2)

$\begin{array}{ll} & \begin{array}{l}0.126^{* *} \\ (0.05)\end{array} \\ & -0.161^{* * *} \\ & (0.05) \\ -0.082 & -0.039 \\ (0.05) & (0.05) \\ 0.024 & 0.024 \\ (0.03) & (0.03) \\ -0.019 & -0.022 \\ (0.05) & (0.05) \\ 0.073^{*} & 0.075^{*} \\ (0.04) & (0.04) \\ 0.035 & 0.036 \\ (0.05) & (0.04) \\ -0.076 & -0.082 \\ (0.06) & (0.06) \\ \end{array}$

(0.06)

816

816

yes

yes

yes

yes

0.004

Notes: We define the permanent sample as firms that we observe continuously from 1990-1996 in Mexico and 1993-2003 in Argentina and Brazil. Sample of HighExporter. The dependent variable is investment normalized by total assets. Post ${ }^{\text {twin }}$ is a dummy variable that takes the value of one in the year of the twin crisis and one year after, the starting depreciation year is 2002 for Argentina and 1995 for Mexico. Post ${ }^{\text {currency }}$ is a dummy variable that takes the value of one in the year of the currency crisis and one year after, the starting depreciation year is 1999 and 2002 in Brazil. ShortDollarDebt is a predetermined variable that takes the value of one if the ratio of short-term dollar denominated liabilities to total short-term liabilities is higher than median value of the distribution of firms holding short-term dollar debt and zero otherwise. Control variables: Leverage is the ratio of total liabilities to total assets; BondAbroad is a dummy that takes the value of one in the year the firm issues a corporate bond abroad; InternationalLoan is a dummy that takes the value of one in the year the firm issues syndicated loans abroad; EquityAbroad is a dummy that takes the value of one in the year the firm issues equity abroad. All control variables are lagged one period. Standard errors are clustered at the firm-year level. ${ }^{*},{ }^{* *}$ and ${ }^{* * *}$ indicate significance at the $10 \%, 5 \%$ and $1 \%$ levels, respectively. 


\section{E Figures}

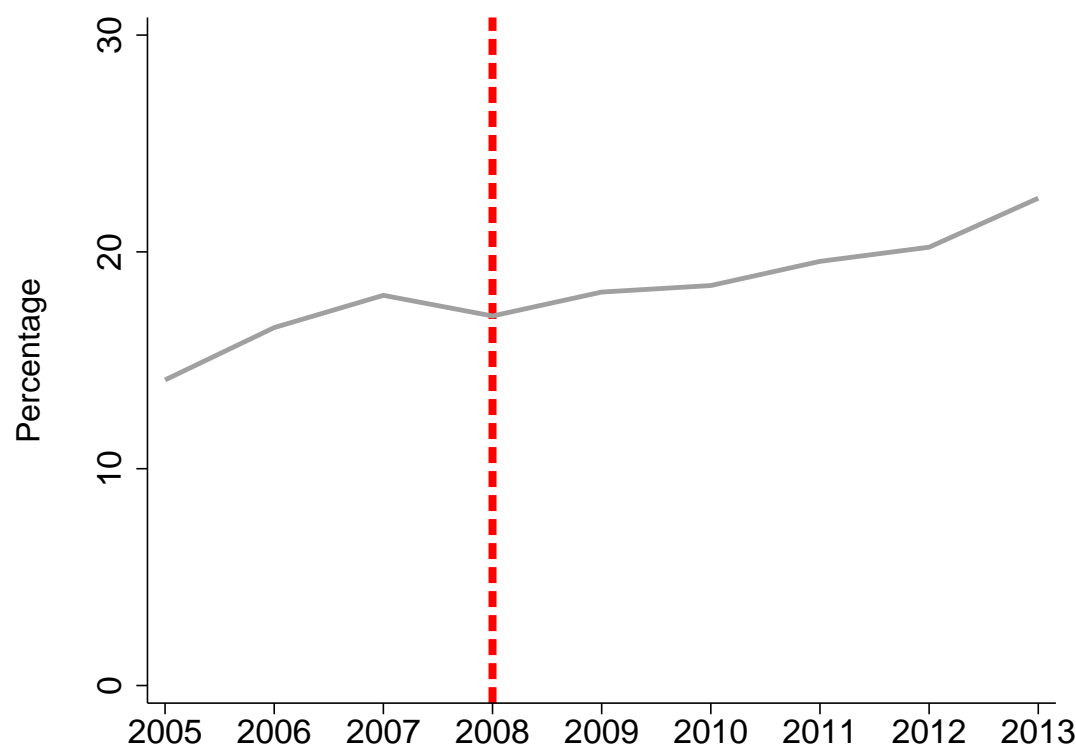

Figure A.1: Domestic credit to private sector by banks, as a share of GDP. WDI Database. 


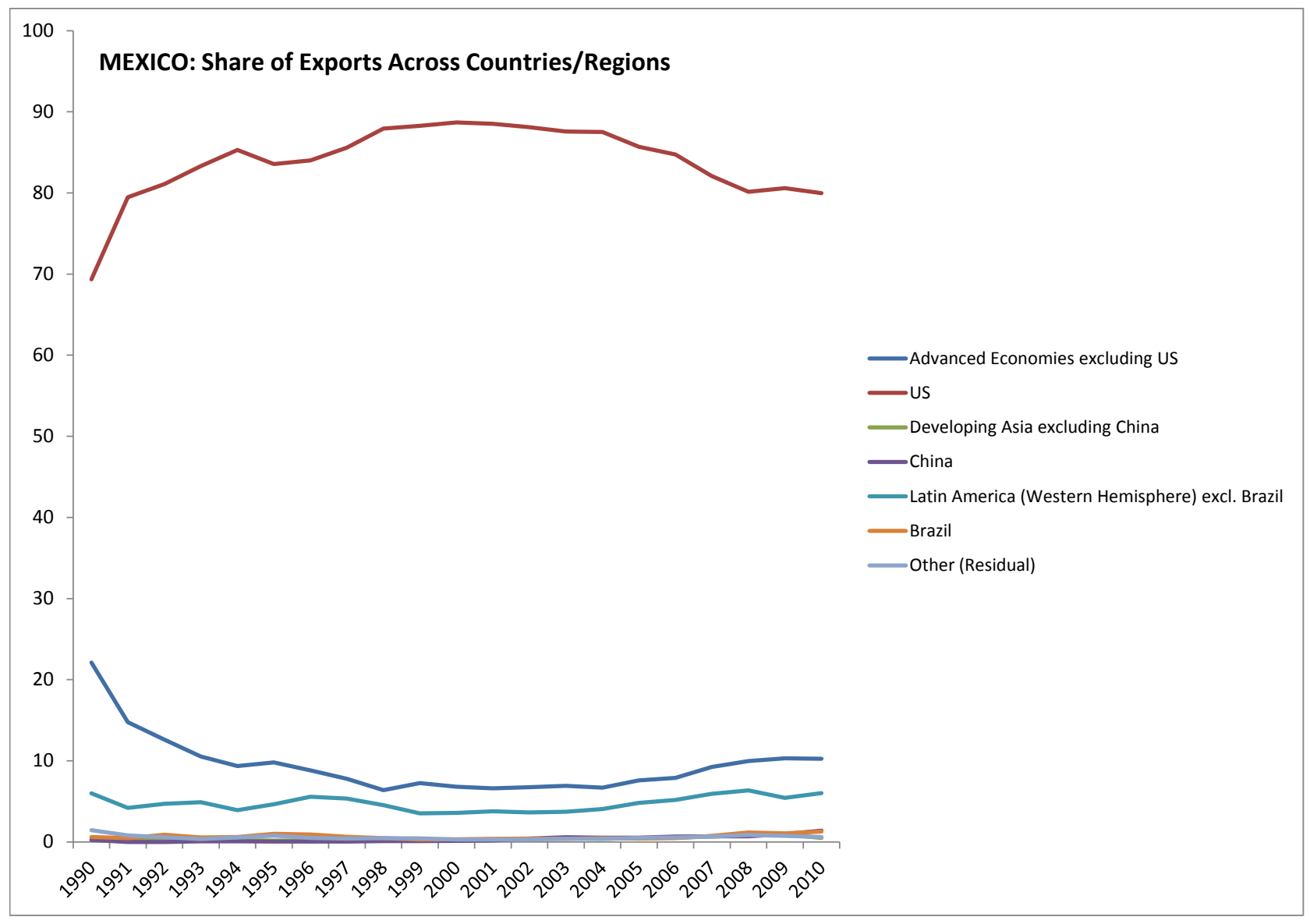

Figure A.2: MEXICO: Share of Exports Across Countries/Regions 